\title{
Amino acids production focusing on fermentation technologies - A review
}

\author{
D'Este, Martina; Alvarado-Morales, Merlin; Angelidaki, Irini
}

Published in:

Biotechnology Advances

Link to article, DOI:

10.1016/j.biotechadv.2017.09.001

Publication date:

2018

Document Version

Peer reviewed version

Link back to DTU Orbit

Citation (APA):

D'Este, M., Alvarado-Morales, M., \& Angelidaki, I. (2018). Amino acids production focusing on fermentation technologies - A review. Biotechnology Advances, 36(1), 14-25.

https://doi.org/10.1016/j.biotechadv.2017.09.001

\section{General rights}

Copyright and moral rights for the publications made accessible in the public portal are retained by the authors and/or other copyright owners and it is a condition of accessing publications that users recognise and abide by the legal requirements associated with these rights.

- Users may download and print one copy of any publication from the public portal for the purpose of private study or research.

- You may not further distribute the material or use it for any profit-making activity or commercial gain

- You may freely distribute the URL identifying the publication in the public portal

If you believe that this document breaches copyright please contact us providing details, and we will remove access to the work immediately and investigate your claim. 


\section{Accepted Manuscript}

Amino acids production focusing on fermentation technologies A review

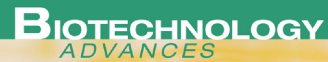

Martina D'Este, Merlin Alvarado-Morales, Irini Angelidaki

PII: S0734-9750(17)30105-2

DOI: doi: 10.1016/j.biotechadv.2017.09.001

Reference:

JBA 7150

To appear in: Biotechnology Advances

Received date: 25 October 2016

Revised date: $\quad 4$ September 2017

Accepted date: $\quad 4$ September 2017

Please cite this article as: Martina D'Este, Merlin Alvarado-Morales, Irini Angelidaki , Amino acids production focusing on fermentation technologies - A review. The address for the corresponding author was captured as affiliation for all authors. Please check if appropriate. Jba(2017), doi: 10.1016/j.biotechadv.2017.09.001

This is a PDF file of an unedited manuscript that has been accepted for publication. As a service to our customers we are providing this early version of the manuscript. The manuscript will undergo copyediting, typesetting, and review of the resulting proof before it is published in its final form. Please note that during the production process errors may be discovered which could affect the content, and all legal disclaimers that apply to the journal pertain. 
Amino acids production focusing on fermentation technologies - A review Martina D'Este $^{\mathrm{a}}$, Merlin Alvarado-Morales ${ }^{\mathrm{a}}$, Irini Angelidaki ${ }^{\mathrm{a}}$

a. Technical University of Denmark, Department of Environmental Engineering, Building 113, DK-2800 Kgs. Lyngby, Denmark.

Corresponding author.E-mail address: iria@env.dtu.dk (I. Angelidaki)

Keywords: amino acids, downstream, fermentation, microorganisms. 


\section{ABSTRACT}

Amino acids are attractive and promising biochemicals with market capacity requirements constantly increasing. Their applicability ranges from animal feed additives, flavour enhancers and ingredients in cosmetic to specialty nutrients in pharmaceutical and medical fields.

This review gives an overview of the processes applied for amino acids production and points out the main advantages and disadvantages of each.

Due to the advances made in the genetic engineering techniques, the biotechnological processes, and in particular the fermentation with the aid of strains such as Corynebacterium glutamicum or Escherichia coli, play a significant role in the industrial production of amino acids. Despite the numerous advantages of the fermentative amino acids production, the process still needs significant improvements leading to increased productivity and reduction of the production costs.

Although the production processes of amino acids have been extensively investigated in previous studies, a comprehensive overview of the developments in bioprocess technology has not been reported yet. This review states the importance of the fermentation process for industrial amino acids production, underlining the strengths and the weaknesses of the process. Moreover, the potential of innovative approaches utilizing macro and microalgae or bacteria are presented. 


\section{Introduction}

Amino acids market demand is increasing since the production of monosodium glutamate (MSG) started in 1907 (Sano, 2009). Amino acids are used in many industrial applications as bulk biochemical to produce a wide range of products such as animal feed additives, flavour enhancers in human nutrition or as ingredients in cosmetic and medical products.

Besides the amino acids important role as intermediates as building blocks of proteins, they are involved in the regulation of key metabolic pathways and processes that are crucial for the growth and the maintenance of organisms (Cesari et al., 2005; Wu, 2009). In particular, they promote health by several actions, including maximizing the efficiency of food utilization, reducing the adiposity, regulating the muscle protein metabolism and controlling the growth and immunity of the organism (Yamane et al., 2007; Wu et al., 2004b; Weinert, 2009). Indeed, it is well documented that an amino acids deficiency causes serious diseases both in humans and animals (Paul et al., 2014; Wu et al., 2004a). Therefore, the interest in investigating and developing new routes to produce them in a more cost-effective and sustainable way has significantly increased in the last years.

Amino acids can be produced by different processes such as extraction from protein hydrolysates, chemical synthesis or enzymatic and fermentation pathways with the aid of microorganisms. In particular, the fermentation process is becoming one of the most promising processes for amino acids commercial production because of the new genetic engineering tools applied to maximize yield, specificity and productivity of the target compounds (Ikeda, 2003).

This paper provides an overview of the different processes used for amino acid production and underlines the main advantages and disadvantages of each method. Moreover, the most common industrially used amino acid producing bacteria Corynebacterium glutamicum and Escherichia coli, are presented. Furthermore, process parameters, technological issues associated to an industrial amino acid plant and possible improvements are also discussed.

\section{Amino acid production}

\subsection{Amino acid production: a short history}

The interest in the production of amino acids has increased over the years resulting in the development of a variety of technologies. In the 1907, Kikunae Ikeda, at the Tokyo Imperial University, started his experiments with the aim of identifying and purifying the flavour enhancing principle from the seaweed konbu (Laminaria japonica). After a year of research he discovered that the extract consisted of MSG (Kurihara, 2009). Soon after his discovery Ajinomoto Co. began extracting MSG from acid-hydrolyzed wheat gluten or defatted soybean and selling it as a flavor enhancer (Sano, 2009). Kikunae Ikeda is considered the father of MSG as he provided the bases for the amino acid production industry.

The development of new applications for amino acids, such as pharmaceutical, food additives, feed supplements, cosmetics, polymer materials and agricultural chemicals, led to a fast increase in the amino acid production. Indeed, in 2008 the total amino acids market was estimated around USD 5.4 billion (März, 2009) and it is expected to be 
worth over USD 9.4 billion by 2018 (Transparency Market Research, 2013). However, the industrial processes to produce amino acids still need to be optimized. For this reason, many companies (Kim 2010) and academic institutions (Kumagai, 2013; Hauer et al., 2004) started research in this field with the aim of finding more cost-effective and sustainable routes to produce amino acids.

\subsection{Amino acid production processes}

Amino acids are at the present produced through three different routes, namely, extraction from protein-hydrolysates, chemical synthesis and microbial processes (enzymatic synthesis and fermentation). In Table 1, the different amino acids production methods are compared and in Table 2 and Table 3 an overview of the yield obtained with the different methods is presented.

\subsubsection{Extraction from protein-hydrolysates}

Extraction from protein-hydrolysates is suitable for large scale industrial production of only a few kinds of amino acids such as L-cysteine, L-leucine and L-tyrosine (Ikeda, 2003). This method exploits the differences in physicochemical properties (such as chemical affinity and $\mathrm{pH}$ ) of the amino acids to separate them (Zhang et al., 2014). According to the amino acid of interest different extraction processes can be developed. For instance, L-cysteine, traditionally produced from keratin contained in animal and human material such as feathers, hair, bristles and hooves, is extracted using activated charcoal and concentrated hydrochloric acid (Renneberg, 2008). The main advantage of this method relies in the use of industrial by-products or wastes, such as hair, meat extracts and plant hydrolysates which are thus exploited for further utilization (Hauer et al., 2004). It is a simple method, the reagents that it requires are easily available and the technological process is well established. Nevertheless, the high $\mathrm{pH}$ conditions could lead to protein degradation resulting in a low amino acids yield (Ikeda, 2003).

Moreover, unwanted reactions, causing molecular rearrangements resulting in formation of toxic compounds or in decrease of the nutritive value in the final product, may take place. Furthermore, the necessary washing out of the alkali solution from the product leads to the generation of large amounts of wastewater (Sereewatthanawut et al., 2008; Lütke-Eversloh et al., 2007).

More effective extraction methods utilizing water at subcritical $\left(100^{\circ} \mathrm{C}<\mathrm{T}<374.2^{\circ} \mathrm{C}\right)$ or supercritical $\left(\mathrm{T}=374.2^{\circ} \mathrm{C}\right.$ and $\left.\mathrm{P}=22.05 \mathrm{MPa}\right)$ conditions have been developed (Klejdus et al., 2008; Sereewatthanawut et al., 2008). Sereewatthanawut et al. (2008) tested the effect of different temperatures and hydrolyses time in a subcritical water process. The results demonstrated that the amino acids yield increases with temperature and time. In particular a higher temperature is associated with an increasing in the dissociation constant of water $\left(\mathrm{K}_{\mathrm{w}}\right)$ and thus the concentration of hydronium and hydroxide ions increases. Therefore, the presence of these ions breaks down the peptide bonds in smaller molecules such as the amino acids. Other examples are L-leucine, Lalanine and L-serine which are produced from proteinaceous biomass waste material derived from animals. These amino acids are extracted in subcritical water, with temperatures ranging from 180 to $320^{\circ} \mathrm{C}$ and pressures from 3 to $30 \mathrm{MPa}$. This study demonstrated that hydrolyses reaction time and temperature are very important to obtain high yield of amino acids. In particular, the maximum yield was obtained at temperatures ranging from 200 to $290^{\circ} \mathrm{C}$ and reaction time from 5 to $10 \mathrm{~min}$ (Cheng et al., 2008). 
Moreover several studies demonstrated that sub- and supercritical methods, utilized to decompose organic matter into smaller molecules, are environmentally friendly (Goto et al., 2004; Pourali et al., 2008). Indeed, using higher temperatures the dielectric constant of water decreases to that of organic compounds. Thus, it is possible to extract organic compounds using water instead of organic solvents which are not environmentally friendly (Pourali et al., 2008).

In general, the main bottleneck of these methods is that they are highly dependent on the availability of natural protein rich resources so that it may be difficult to satisfy the increasing demand of amino acids.

\subsubsection{Chemical synthesis}

Historically, chemical synthesis has been the classical pathway to produce achiral amino acids like glycine or a racemic mixture of D, L-methionine or D, L-alanine. The first amino acid synthesis was reported in 1850 with the name of Strecker synthesis. According to this reaction the conversion of an aldehyde or ketone and amine or ammonia to $\alpha$-amino acids can be achieved by means of an acid catalysts, metal cyanide and water (Strecker, 1850). In particular it consists in the reaction of an aldehyde with hydrogen cyanide and D- $\alpha$-methylbenzylamine in methanol, followed by the hydrolysis of the resulting amino nitrile to yield the $\mathrm{N}-\alpha$-methylbenzyl amino acid. Finally, a catalytic hydrogenolysis is performed to remove the methylbenzyl group from the amino acid molecule. Examples of chemical synthesis are the ammonolysis of trichloroethylene to glycine (Inoue and Enomoto, 1981) or the ammonolysis of $( \pm)$-2chloropropionic acid to D,L-alanine (Ogata and Inaishi, 1981). These studies analyzed the effect of ammonia molar ratio, reaction time, pressure and temperature on the yield of amino acids. Inoue and Enomoto (1981) demonstrated that a higher yield of glycine (from $40 \%$ to $70 \% \mathrm{w} \mathrm{w}^{-1}$ ) was obtained after $4 \mathrm{~h}$ reaction at a temperature of $180{ }^{\circ} \mathrm{C}$. Ogata and Inaishi (1981) obtained a D,L-alanine yield of $78 \%$ in $7 \mathrm{~h}$ reaction at a temperature of $70{ }^{\circ} \mathrm{C}$ and ammonia concentration of $22.2 \mathrm{M}$. However, the main drawbacks of the chemical synthesis are associated to the price of the catalyst as well as to the use of hazardous cyanide sources (Zuend et al., 2009). Moreover, the Strecker synthesis is not enantioselective and therefore it can produce only a mixture of D and L forms of amino acids (Gröger, 2003). To overcome these problems new methods, such as the catalytic asymmetric Strecker-type reaction introduced in 1963 by Harada et al. (1963), using a chiral amino-thiourea catalyst compatible with the safer aqueous cyanide salts, have been developed (Zuend et al., 2009). Moreover, these catalysts, controlling the hydrocyanation step, are able to selectively increase the synthesis of a particular enantiomer.

The most common industrial chemical process for the manufacture of racemic amino acids is the so-called Bucherer-Bergs method which is a variant of the Strecker synthesis. According to Bucherer-Bergs method ketones or aldehydes react with ammonium carbonate and sodium cyanide to produce hydantoions, followed by hydrolysis of the racemic amino acid mixture in a basic medium (Hauer et al., 2004). Even if these processes have not yet reached the goal of producing enantiomerically pure amino acids, the synthesis of racemic mixtures is of considerable importance because they can be further converted readily in target compounds through biochemical methods. For instance, to obtain only the desired L-form is required an additional optical resolution step, consisting in a chemical or enzymatic procedure where a chemical substance or an enzyme such as Aspergillus fumigatus (Singh et al., 2011) can 
resolve the amino acids. Although the Bucherer-Bergs approach is the most common because of its simplicity and effectiveness, the main drawbacks of this method are the long reaction times and the elevated temperatures (Heuer et al., 2004).

\subsubsection{Microbial process}

The last route to produce amino acids is through biological processes such as enzymatically catalyzed synthesis and fermentation. The enzymatic process is based on the action of an enzyme or a combination of them to catalyze the production of the desired amino acids. Several enzymes have been used such as hydrolytic enzymes, ammonia lyases, $\mathrm{NAD}^{+}$-dependent L-amino acid dehydrogenases (Pollegioni et al., 2003). Most of these enzymes are obtained from microorganisms such as Escherichia coli, Saccharomyces cerevisiae, Pseudomonas dacunhae, Crypotococcus lurendii. The main advantage of the enzymatic route is that it can produce optically pure $\mathrm{D}$ and L- amino acids in higher concentrations and with a very low by-products formation (Ikeda, 2003). An example of enzymatic extraction of amino acids in small scale industries is carried out using dried fish protein and the enzymes Alcalase and Neutrase (Ramakrishnan et al., 2013). Ramakrishnan et al. (2013) analysed the effect of reaction time on the hydrolysis process. The highest yield of amino acids was obtained with a combination of enzymes (Alcalase and Neutrase) and a reaction time of $48 \mathrm{~h}$. On the other hand the enzymes are usually expensive and their limited stability is one of the main drawbacks of this process (Ikeda, 2003). Therefore, various techniques based on immobilized biocatalysts have been developed in order to improve the performance of the process. Indeed, Hsiao et al. (1988) demonstrated that using E. coli immobilized by polyazetidine the L-phenylalanine yield increases up to $63 \%\left(\mathrm{~W} \mathrm{w}^{-1}\right)$. However this is not the best method to produce L-amino acids at industrial scale and it is used only for the production of some amino acids such as L-aspartic acid and L-alanine (Zhao et al., 2014).

Most of the current industrial processes for amino acids production are based on fermentation route. Under aerobic or anaerobic conditions, several microorganisms are used to convert the sugars present in a substrate into a broad spectrum of amino acids. This process has several advantages compared to the other methods. First of all, it produces only the L-form amino acids avoiding further purification steps. Another important factor is that it can be operated at mild conditions preventing product degradation (Ugimoto, 2010). Furthermore, the maintenance costs are significantly lower compared to the extraction processes (Ugimoto, 2010). On the other hand, fermentation requires sterility and high energy consumption for oxygen transfer (for the aerobic fermentations) and mixing as well as water addition that impact on capital and operation costs. Moreover, requirement of bigger reactors, compared to the other amino acids production methods, leads to a high capital investment (Ivanov et al., 2014). The choice of the best amino acid production method is done analyzing several criteria such as available technologies and capital investments, product market size and revenues, raw materials and operation costs as well as environmental impact of each specific process. However, mainly due to economic and environmental advantages, fermentation is the most used process at industrial scale (Ikeda, 2003). 


\section{The fermentation process}

\subsection{Amino acid producing bacteria}

The most common bacteria used for amino acid production via fermentation, are $C$. glutamicum and E. coli (Ikeda, 2003). Both can produce a broad spectrum of amino acids and several metabolic engineering alterations have been applied to improve their performance as amino acid producing organisms.

Genetically modified $C$. glutamicum is used to produce lysine or glutamic acid (Becker et al., 2011) with high yields (up to $50 \% \mathrm{w} \mathrm{w}^{-1}$ ) (Aoki et al., 2005), while E. coli has been modified to enable the production of the extremely interesting aromatic amino acids such as L-tryptophan, L-phenylalanine and L-tyrosine (Rodriguez et al., 2014a) (Table 3).

\subsubsection{Corynebacterium glutamicum}

C. glutamicum is an aerobic non-pathogenic Gram positive soil bacterium, widely used in the amino acid production industry and it represents the main amino acids producing bacterium.

C. glutamicum is used for the production of several amino acids such as L-glutamate, Llysine, L-phenylalanine (Hermann, 2003), L-threonine (Kumagai, 2000), L-tryptophan (Leuchtenberger et al., 2005), L-serine, L-proline, L-glutamine, L-arginine (Utagawa, 2004) and L-isoleucine. It prefers glucose as carbon source (Eggeling and Bott, 2005), but it can utilize also other sugars such as sucrose, fructose, ribose, mannose and maltose (Zahoor et al., 2012). Its optimal growth conditions are at a temperature of $30^{\circ} \mathrm{C}$ and a $\mathrm{pH}$ of 7 (Liebl, 2005). Inhibition studies have been done to determine if growth inhibition by substrate and product occurs. It has been demonstrated that with a glucose concentration above $50 \mathrm{~g} \mathrm{~L}^{-1}$ and with a L-glutamic acid concentration of $12 \mathrm{~g}$ $\mathrm{L}^{-1}$ the growth decreases (Khan et al., 2005).

\subsubsection{Central carbon metabolism of Corynebacterium glutamicum}

The biosynthesis of the amino acids is closely linked to the central metabolism of the microorganism. Therefore, being an important microorganism for the amino acid production industry, $C$. glutamicum has been subject of biochemical, physiological and genetic studies for several years. Isotopic tracer methods, such as $\left[{ }^{13} \mathrm{C}\right]$-labelling techniques, have been combined with metabolite balancing (Sahm et al., 2000) to achieve a better understanding of the central metabolism of $C$. glutamicum and quantifying the in vivo fluxes.

Three main pathways have been identified: Embden-Meyerhof-Parnas pathway (glycolysis), the pentose phosphate pathway (PPP) and the tricarboxylic acid (TCA) cycle (Ikeda, 2003) (Yukawa and Inui, 2013). Different enzymes are involved in the conversion of carbon between TCA cycle and glycolysis such as 6-phosphogluconate dehydrogenase and isocitrate dehydrogenase (Yukawa and Inui, 2013).

In the glycolysis, responsible of a further catabolism of the sugars, glucose is converted into pyruvate and energy carriers such as ATP and NADH (figure 1).

In the phosphoenolpyruvate (PEP) -pyruvate oxaloacetate node, PEP and pyruvate, end products of glycolysis, enter into the TCA cycle (Yukawa and Inui, 2013).

The TCA cycle (Figure 2), is composed by a catabolic and an anabolic phase. During the catabolic phase, the acetyl-CoA, produced by the degradation of sugars, is oxidized through several steps in $\mathrm{CO}_{2}$, simultaneously generating NADH (Bott, 2007). During the anabolic phase, the TCA cycle produces two precursors of the glutamate and 
aspartate family of amino acids, 2-oxoglutarate and oxaloacetate, besides other intermediates such as succinyl-CoA.

The PPP is responsible for providing the anabolic reducing power NADPH and ribose 5-phospate and erythrose 4-phospate, two precursors for the biosynthesis of building blocks (Stincone et al., 2015). Moreover, during the cycle, vitamins and cell wall constituents essential for the production of amino acids are produced.

Lysine is produced converting its precursor oxaloacetate to aspartate with the aid of the aspB-gene-product (Wittmann and Becker, 2007). Aspartate is then phosphorylated to L-4-aspartyl phosphate by the aspartate kinase enzyme (AK), which is in turn converted to L-aspartate 4-semialdehyde by the enzyme aspartate-semialdehyde dehydrogenase (ASADH). L-aspartate 4-semialdehyde is further converted to dehydrodipicolinate by reacting with pyruvate, catalysed by dehydrodipicolinate synthase (DHDPS). Lpiperidine 2,6-dicarboxylate is produced with the aid of the reducing agent NADPH and the enzyme dehydrodipicolinate reductase (DHDPR). L-piperidine 2,6-dicarboxylate can be directly converted to meso-2,6-diaminopimelate adding an amino-group, process called dehydrogenase variant and catalyzed by diamino pimelate dehydrogenase (DAPDH), or by the succinyl variant where several reactions are involved. Finally, the meso-2,6-diaminopimelate is decarboxylated to lysine by means of the enzyme diaminopimelate decarboxylase (DAPDC). The biosynthetic pathway of L-lysine from glucose is shown in Figure 3.

\subsubsection{Strain improvement}

The development of innovative techniques in genome analysis enabled a better understanding of this microbe (Ikeda and Nakagawa, 2003). Therefore, metabolic engineering strategies involving point mutations in genes relevant for the target amino acid (Volker, 2006) have been applied in order to maximize its performance such as yield, fermentable carbon sources and the products that can be obtained from this bacterium.

Moreover metabolic engineering tools enable the development of more environmentally sustainable technologies (Zahoor et al., 2012; Rittmann et al., 2008). Indeed, the construction of a recombinant strain allows not only to use a larger range of carbon sources including galactose, lactose, xylose or arabinose, but also alternative feedstocks, such as glycerol, which can be found in industrial by products, and thereby do not compete with food or energy production (Ikeda and Takeno, 2013). The success of these techniques is due to various approaches optimising the entire cellular system involving central metabolism, uptake and export systems, energy metabolism, stress response and global regulation (Ikeda and Takeno, 2013).

Previous studies demonstrated that $C$. glutamicum requires high amounts of NADPH to overproduce amino acids such as L-lysine and L-isoleucine (Moritz et al., 2000; Bommareddy et al., 2014). Several techniques have been tested to enhance the production of NADPH, most of them focused on manipulations to increase the fluxes of the PPP, the main producer of this high energy molecule. One of the most innovative procedures is the engineering of new enzymes, such as glyceraldehyde 3-phosphate dehydrogenase (GAPDH), which can produce 2 moles of NADPH from 1 moles of glucose (Bommareddy et al., 2014) leading to a higher yield of the target amino acid. Moreover, innovative approaches utilizing CRISPR interference (CRISPRi) to modify quickly and efficiently the metabolic pathway without gene deletions and mutation has been recently developed (Cleto et al., 2016) (see section 3.2.7 for more details). 


\subsubsection{Escherichia coli}

E. coli is an aerobic Gram-negative bacterium commonly found in plants and member of the normal intestinal flora in mammals (Gordon, 2013).

It is a well-known microorganism used to produce several amino acids such as Lmethionine, L-lysine and L-threonine (Ikeda and Takeno, 2013) and the aromatic amino acids, L-phenylalanine, L-tyrosine and L-tryptophan. Moreover, metabolic engineering techniques by means of site-specific mutagenesis, transcriptional attenuation regulations and modification of the pathway by depletion of specific genes, enable the creation of a mutant strain of E. coli, able to produce the branched chain amino acids L-valine, Lleucine and L-isoleucine which are extremely interesting for their potential as feed additives, cosmetics and pharmaceuticals (Park and Lee, 2010).

The main substrates that $E$. coli is able to ferment are glucose, sucrose, mannose, xylose, arabinose, galactose and fructose (Sabri et al., 2013; Desai and Rao, 2010; Ikeda, 2003). The optimum growth conditions are at a temperature of $37^{\circ} \mathrm{C}$ and a pH of 7 (Noor et al., 2013).

\subsubsection{Central carbon metabolism of Escherichia coli}

E.coli central carbon metabolism consists of three main pathways such as EmbdenMeyerhof-Parnas pathway (glycolysis), the PPP and the TCA cycle. In particular, the PPP is responsible for the breakdown of the carbon sources that $E$. coli utilizes for the biosynthesis of amino acids. Moreover, the PPP generates the reducing power NADPH necessary to their synthesis (Figure 4 ). In E. coli the PPP occurs in two phases: oxidative and non-oxidative. During the oxidative phase of the cycle $\mathrm{CO}_{2}$ together with intermediate five carbon sugar ribulose-5-phospate are produced. While during the nonoxidative phase the D-ribulose-5-phospate is converted into D-fructose-6-phosphate and D-glyceraldehyde-3-phosphate (Sprenger, 1995). In the first step of the oxidative branch, glucose is phosphorylated to glucose-6-phosphate by means of the hexokinase enzyme. Glucose 6-phosphate dehydrogenase (G6PD) catalyzed the dehydrogenation of glucose-6-phosphate to 6-phospho-D-glucono-1,5-lactone with the production of NADPH. G6PD has been intensively studied in recent years for being a branching point in the PPP and for being essential in the formation of NADPH (Sprenger, 1995). The regulation of this enzyme is strictly correlated to the carbon source used to grow E. coli. Previous studies demonstrated that cells grown on glucose has a cellular growth rate fourfold higher that cells grown on acetate (Sprenger, 1995). The following step in the PPP is the hydration of 6-phospho-D-glucono-1,5-lactone to 6-phospho-D-gluconate by means of 6-phosphogluconolactonase (PGLS) and finally 6-phospho-D-gluconate is converted to D-ribulose-5-phosphate through an oxidative decarboxylation reaction catalyzed by 6-phosphogluconate dehydrogenase (6PGD). In the non oxidative branch, through several steps catalyzed by transketolase enzyme (TKT), D-ribulose-5-phosphate is converted to D-glyceraldehyde-3-phosphate and D-fructose-6-phosphate.

\subsubsection{Strain improvement}

E. coli has been genetically modified in order to expand the range of substrates that can be utilized and enhance the productivity of different and important amino acids, particularly branched amino acids such as L-isoleucine (Park et al., 2012). Furthermore, developments in bioprocess engineering and biology concerning the generation, characterization and optimization of E.coli, have led to an improvement in the production of aromatic amino acids (AAA) such as L-tryptophan, L-phenylalanine and 
L-tyrosine produced through the shikimate pathway (Rodriguez et al., 2014). In this pathway (Figure 5) the PEP and the D-erythrose-4-phosphate, produced through the central carbon pathway, are combined to form 3-deoxy-D-arabino-heptulosonate-7phosphate (DAHP) and then converted to chorismate, the precursor in the AAA synthesis (Rodriguez et al., 2014) (Koma et al., 2012). In particular, to increase the production of AAA, techniques aiming at increasing the availability of precursors such as PEP and erythrose-4-phosphate, enhancing the carbon flow through the pathway (Bongaerts et al., 2001) and identifying the rate-limiting enzymatic reactions have been applied (Koma et al., 2012). Modifications such as overexpression of transketolase $(t k t A)$ and PEP synthase ( $p p s)$ genes, deletion of PEP carboxylase gene ( $p p c)$ (Yakandawa et al., 2008), overexpression or deletion of carbon storage regulator genes ( $\operatorname{csr} A$ or $\operatorname{csr} B$ ) (Tatarko and Romeo, 2001) and glucose transport system exchange have been used (Yi et al., 2003). In the production of L-phenylalanine the enzymes involved in the most important steps of the shikimate pathway, DAHP synthase (aroG) and chorismate mutase/prephenate dehydrase (pheA), are inhibited by the L-phenylalanine production. These enzymes are controlled by the transcriptional repressor tyrR. Therefore, the deletion of $t y r R$ leaded to a higher L-phenylalanine production (Pittard et al., 2005).

\subsection{Process design in amino acid production}

\subsubsection{Process monitoring}

In a fermentation process, constant monitoring of crucial parameters and process variables such as quality of inoculum, $\mathrm{pH}$, feed rate, aeration intensity and process temperature is required (Scheper and Lammers, 1994).

Moreover, the inoculum preparation is a key step in a bioprocess since it could significantly influence the productivity and yield (Ikeda, 2003; Hermann, 2003). Therefore to ensure the optimal state for inoculation, inoculum stability and productivity should be thoroughly tested before being transferred to the main fermentor. Furthermore, to avoid contaminations, sterility has to be maintained throughout the process. Thus continuous sterilization systems have been integrated in the classical fermentor configuration to ensure aseptic condition during all the stages of the process (Junker et al., 2006).

It has been demonstrated that according to the biochemical characteristics of the amino acids the oxygen transfer rate (OTR) influences the productivity (Villadsen et al., 2011). Indeed it has been shown that an increment in the OTR has led to a $45 \%$ higher Lphenylalanine productivity and yield (Shu and Liao, 2002) while the L-tryptophan production was favored by lower oxygen transfer conditions since the carbon flow towards the aromatic amino acid pathway increases (Kocabaş et al., 2006).

Also the process temperature has to be carefully chosen taking into consideration the target compound to be produced. Indeed in some studies on C. glutamicum a high temperature (up to $41^{\circ} \mathrm{C}$ ) has been used to increase the productivity of some amino acids such as L-glutamic acid (Delaunay et al., 2002). Furthermore thermotolerant bacteria, such as Bacillus methanolicus, that can produce L-lysine and L-glutamate at temperatures up to $50{ }^{\circ} \mathrm{C}$, are being investigated (Brautaset et al., 2007). Indeed a higher growth temperature represents an advantage with respect to the lower amount of cooling water required for the reactor (Hermann, 2003). 


\subsubsection{Fed-batch production}

The most common reactor operation mode used in the amino acid industry is the fedbatch operation (Ikeda, 2003). In this configuration the process is started with only a small amount of medium and inoculum. The carbon source is fed in the reactor following a pre-defined feed profile developed to obtain higher yield or productivity. During this procedure no effluent is withdrawn and both cell and products remain in the reactor. The nutrients necessary to perform the fermentation, such as ammonium sulfate or pure ammonia, biotin and other vitamins, are supplied at the beginning with the inoculum (Hermann, 2003). This configuration ensures an adequate oxygen capacity to satisfy the oxygen demand, preventing oxygen limitation in the culture with consequent formation of undesired by-products (Hermann, 2003). Thereby a better control of the nutrient concentration and therefore an increased productivity and yield are achieved (Hermann, 2003). In particular, in the study of Abou-taleb (Abou-taleb, 2013) the performance of Bacillus sp. in a batch and fed-batch configuration were compared. They demonstrated that the fed-batch process outcompeted the batch with a total amino acids concentration of $4.5 \mathrm{~g} \mathrm{~L}^{-1}$ and $2.8 \mathrm{~g} \mathrm{~L}^{-1}$, respectively. Despite its simplicity in terms of process control and technology, the batch configuration has a lower productivity and reproducibility compared to the fed-batch procedure (Longobardi, 1994). The important rationale of fed batch operations are not only the aforementioned increased process performance, but also the increased process reproducibility and the reduced inhibition risk due to the high carbon content at the beginning of the fermentation (Gnoth et al., 2007).

\subsubsection{Continuous production}

This operation mode can provide productivity and process outputs 2.5 fold higher than the fed-batch technology (Ikeda, 2003). However, the main drawbacks of this configuration process are the increased contamination risk, due to the continuous flows into and from the reactor, and the possible strain instabilities caused by the continuous changes in the working conditions (Hermann, 2003). Previous studies demonstrated the potential of the continuous processes. In particular, Koyoma et al. showed that the productivity of L-glutamic acid achieved by means of Brevibacterium lactofermentum in a continuous configuration, doubled the one achieved with the batch process, reaching $8 \mathrm{~g} \mathrm{~L}^{-1} \mathrm{~h}^{-1}$ (Koyoma et al., 1998).

Moreover, to improve the performance of the continuous configuration, a cascade bioprocess may be applied. According to this methodology the microorganisms' growth phase can be done in a separated reactor than the production process itself, allowing optimized conditions in both the phases. Moreover, higher growth rates allow lower residence time with consequent smaller bioreactors and higher productivities (Hermann, 2003).

\subsubsection{Downstream separation and purification}

An efficient downstream and purification process is crucial to reduce the costs related to the amino acids production (Hermann, 2003). The separation of the amino acids from the fermentation broth is usually done by centrifugation or filtration followed by a purification step using chromatographic techniques chosen according to the product properties such as solubility, isoelectric point and affinity to adsorbent (Hermann, 2003). However, a significant loss of products, due to the numerous removal steps required in the purification phase, and the high costs associated to the production of 
high purity amino acids, represent the main disadvantages of the process (Hermann, 2003; Kumar et al., 2014). Therefore, membrane-based processes, because of their high selectivity combined with low demand of heat inputs, are gaining increasing interest (Kumar et al., 2014). The most common membrane-based process to separate target amino acids is ion exchange chromatography (Kumar et al., 2014). Furthermore, new techniques have being investigated in order to increase the processes performance and hence raise the revenues. Nanofiltration is an innovative technique among the pressure driven membrane filtration methods (Mänttäri et al., 2013, Ecker et al., 2012). These membranes can be easily integrated with the conventional fermentors combining production and purification in the same operation unit and therefore reducing the capital investment (Kumar et al., 2014).

\subsubsection{Process modelling and analysis}

Another key factor in the amino acid fermentation industry is the fermentor scale-up (Takors, 2012). In a larger scale reactor, the different geometry and physical conditions may affect important parameters leading to a lower process stability, reproducibility and yields and to the formation of unwanted by-products that may affect the final product quality (Takors, 2012). In particular, industrial bioprocesses are often affected by lower mixing efficiency with consequent long mixing times that, combined with the high metabolic activity of microbial cells, results in the formation of local gradients into the bioreactors (Lara et al., 2006). Moreover, this problem is compounded by the increased reactor size. According to the conventional fermentor design, the substrate is supplied from the top, while the aeration from the bottom. The concentration gradients of substrate and oxygen follow an opposite trend along the reactor height. In an industrial fermentor these gradients are more pronounced due to a longer distance to be covered, leading to larger substrate and oxygen depletion zones, larger volumes of culture broth to be stirred thereby longer mixing time as well as stronger hydraulic pressure gradient influencing the oxygen transfer rate (Lara et al., 2006). Therefore, the microorganisms at the top of the fermentor are simultaneously exposed to a high sugar concentration together with oxygen limitations, while the one at the bottom are exposed to glucose restrictions (Schmidt, 2005). Therefore, as a consequence of the combined high glucose concentration and oxygen limitation in the reactor, acetate, ethanol, lactate, hydrogen, succinate and formate are produced in high amounts (Castan and Enfors, 2001). These acid products lead to an acidification of the medium that, together with the excessive heat generated by the agitation, induce the formation of zones with stress conditions where the microorganisms cannot perform well (Bylund et al., 1998). To investigate the impact of these parameters on an industrial process several techniques such as computational fluid dynamics (CFD) and scale down approaches have been applied.

\subsubsection{Scale down approach}

Scale down devices are gaining increasing attention as tools for imitating the large scale bio-reactors conditions and thereby to predict reductions of yield and productivity (Takors, 2012). Two-stirred tank reactors or a stirred tank followed by a plug flow are the most common configurations (Takors, 2012). Such devices are used to generate oscillating supply conditions within laboratory bioprocesses, enabling the selection of a robust strain and enhancing the transferability of the process from small to a bigger scale (Neubauer and Junne, 2010). However, in order to have an appropriate prediction model of the large scale reactor performance, the scale down design has to be tailored to 
the corresponding conditions of the industrial process (Delvigne et al., 2006). The potential of the scale-down approach is underlined in several publications such as in the work of Enfors et al. (Enfors et al., 2001) where comparison among a big scale, a lab scale and a scale-down reactor using E. coli is presented. Moreover, in Käß et al. (Käß et al., 2014), as well as in Lemoine at al. (Lemoine et al., 2015), the effect of the process inhomogeneity and oscillatory conditions on C. glutamicum have been investigated.

\subsubsection{Computational Fluid Dynamics (CFD)}

Process modelling can support the design and the optimization of all these processes. Models, considering the process operative parameters, process stoichiometry and the environmental aspects (Elmar et al., 2007), give an estimation of the process efficiency, the product titer, selectivity as well as the condition for an optimal yield. Moreover, CFD methods can be performed to get a mathematical abstraction of the mixing behavior. Based on the Reynolds averaged Navier-Stokes equations and the EulerianEulerian two phase approach, CFD methods simulate the turbulent flow behavior of an industrial-size reactor (Campolo et al., 2002). The final results provide detailed information regarding the fluid velocity, the temperatures as well as the concentration profile throughout the reactor.

Such approach can help in the optimization of existing processes but above all it represents a useful support to develop new plants. Combining the results obtained by the models with the data obtained by the scale down devices, the optimal process configuration can be identified in an early phase of development.

Therefore, although several studies have been done in the computational field, better simulators are needed to further support scale-up.

\subsubsection{Process integration opportunities: process intensification}

Another important tool to enhance the productivity of an amino acid fermentation process is the process intensification (PI). PI is defined as any technological development that lead to a safer, cleaner and more energy efficient process (Babi et al., 2016). In this field two different approaches can be followed: intensification of the equipment such as new reactors, heat exchangers or mass transfer units, or intensification of the process itself using innovative separations strategies or techniques (Vaghari et al., 2015). For example, changing the reactor configuration (operation mode) to repeated batch or fed-batch reactors, may lead to a lysine productivity that is twice that of the batch (Ikeda, 2003). According to this configuration, after the first batch or fed-batch operation, a portion of $60 \%$ and $90 \%$ of the final broth is transferred to the downstream while the other part remains in the vessel (Hermann, 2003). The reactor is then refilled with fresh medium to its starting working volume and the next fermentation starts regularly. Reducing the time needed to introduce new inoculum in the system and the down time to prepare the sterile bioreactor, a shorter fermentation time, with a higher productivity and a significant improvement in the process economics can be obtained (Ikeda, 2003).

Moreover, membranes are good examples of innovative separation strategies; they enable to improve the performance of processes and to achieve a more efficient transport of specific compounds (Drioli et al., 2011). Recently, electro-membrane filtration was applied for the separation of amino acids (Kattan Readi et al., 2014). In particular, Kumar et al. demonstrated that electro-membranes enable the separation of L-glutamic acid and L-lysine, because of the opposite charge of the two amino acids due to their different isoelectric point. Combining the effect of the iso-electric 
separation with the membrane selectivity a L-glutamic acid recovery of $85 \%$ was achieved, demonstrating the great potential of these techniques for industrial applications (Kumar et al., 2010). This approach integrates the reaction with the separation of the biomolecules in the same operation units leading to the possibility for process intensification (Kattan Readi et al., 2014).

\subsubsection{Novel approaches}

In the past, most of the microorganisms were modified by random mutagenesis. However, the random distribution of mutations can cause unwanted modifications, growth defects and genetically unstable microorganisms. The development of omics technologies combined with computational analyses, enabled to target specific genes, knocking out or introducing them into the microorganisms, with a consequent rational metabolic engineering of the bacterial strains (Chen et al., 2013). New technologies using advanced synthetic biology and metabolic engineering techniques have been applied to increase the microbial cells productivity (Hirasawa and Shimizu, 2016; Zhou and Zeng, 2015a). Park et al. (2007) demonstrated that a rational engineering of $E$. coli increased the production of L-valine up to $0.378 \mathrm{~g}$ of L-valine per $\mathrm{g}$ of glucose. In their study metabolic engineering strategies involving the removal of feedback inhibition and transcriptional attenuation by site-direct mutagenesis have been successfully implemented. Transcriptional attenuation sites were removed by homologous recombination with the tac promoter. Feedback inhibition in AHAS III was removed by substitution of the $41^{\text {st }}$ base $\mathrm{G}$ with $\mathrm{A}$ and of the $50^{\text {th }}$ base $\mathrm{C}$ with $\mathrm{T}$. Moreover, the carbon flux toward L-valine synthesis was increased knocking out the ilvA gene responsible for encoding L-threonine dehydratase. The engineered strain was able to produce $60.7 \mathrm{~g}$ of $\mathrm{L}$-valine per L without by-product formation.

Furthermore, since the central genes for metabolism directly impact the production of amino acids, techniques such as riboswitch and CRISPRi enable the construction of optimized microorganisms, improving the production of amino acids and other high value chemicals (Zhou and Zeng, 2015b; Wendisch et al., 2016). CRISPRi interference technology with the deactivated Cas9 protein (dCas9) was used by Cleto et al. (2016) to determine the effect of target gene repression on L-lysine and the L-glutamate production. In their study they demonstrated that the application of CRISPRi/dCas9mediated for pathway engineering in $C$. glutamicum strongly enhanced L-lysine and the L-glutamate production. $p g i, p c k$, and $p y k$ genes, coding for enzymes involved in the production of these two amino acids, were selected as targets for repression using sgRNA/dCas9. They proved that the deletion of $p g i$ leads to an overproduction of NADPH though the pentose phosphate pathway with a consequent higher L-lysine yield. Moreover, the deletion of $p c k$ and $p y k$ genes, results in an accumulation of Lglutamate through an enhanced flux of oxaloacetate in the TCA cycle, due to the absence of the transformation of oxaloacetate to phospoenolpyruvate. They demonstrated that final L-lysine and L-glutamate yields obtained with the reduced expression of $p g i, p c k$, and pyk genes are comparable to the one obtained by gene deletion (Cleto et al., 2016).

Therefore CRISPRi represents a quick and efficient solution to modify the pathway without complex gene deletions or mutations (Dominguez et al., 2016).

Moreover, innovative approaches to increase the amino acids content by means of a protein up-concentration technique have recently been developed. The approach consists of extracting the carbohydrate fraction through enzymatic hydrolysis $(\mathrm{EH})$-to 
produce fermentable sugars - and obtaining a residue rich in proteins. This approach was demonstrated by Alvarado-Morales et al. (2015). Alvarado-Morales et al. (2015) used macroalgae Laminaria digitata as a substrate, which mainly consists of carbohydrates and to a lesser extent proteins. As a first step EH was performed to convert the carbohydrate fraction in fermentable sugars (mainly glucose and mannitol). Then, the liquid hydrolysate was separated from the solid leftover by centrifugation and the proteins were quantified. The leftover residue after EH had a protein content 3.5 fold higher than the original substrate. Moreover, the proteins bioavailability and digestibility, after the removal of the cell wall polysaccharides, are increased, resulting in a higher nutritional value of the protein (Fleurence, 1999).

With this approach a final product rich in proteins with potential applications as bioactive compound in food or feed as well as in pharmaceutics can be produced without targeting a particular amino acid.

A different methodology to produce proteins is represented by the growth of cells of microorganisms suitable for the production of single cell proteins (SCP) (Suman et al., 2015). Numerous microbes, such as algae, fungi, yeast and bacteria (methylotrophs and hydrogen-oxidizing bacteria) and a variety of inexpensive substrates and wastes are suitable for the production of SCP (Nasseri et al., 2011). Moreover these microorganisms are able to accumulate extremely high amounts of other compounds such as fats, carbohydrates, nucleic acids, vitamins and minerals. Furthermore they are rich in essential amino acids. These features make them excellent candidates to produce protein supplements in human or food nutrition. Recently an innovative approach that combines the growth of bacteria with the conversion of nitrogen and carbon dioxide recovered from wastewater streams have been proposed (Matassa et al., 2016). Therefore, autotrophic hydrogen-oxidizing bacteria (HOB), capable of oxidizing hydrogen and fixing carbon dioxide into cells, have been studied. Moreover, the final HOB composition is characterized by all the essential amino acids, enabling their utilization as high quality protein source for human and animal nutrition (Matassa et al., 2016).

Another novel approach to enhance the protein content in the final product is the utilization of macrophytes such as microalgae. These unicellular species are able to accumulate proteins to a large extent, achieving a composition ranging from $40 \%$ to $70 \%$ of the dry weight (Gatenby et al., 2003; Becker, 2007; Costard et al., 2012). The use of microalgae can offer several advantages. They can grow very rapidly, with a doubling time of few hours, in a wide range of aquatic environments including freshwater, biomass hydrolysates (Xu et al., 2006) as well as wastewaters (Ramos Tercero et al., 2014). Moreover microalgae can utilize the residual sugars presented in industrial waste-streams (Bumbak et al., 2011).

To demonstrate their versatility Chlorella protothekoides was grown heterotropically utilizing the sugars presented in the hydrolysate macroalga $L$. digitata (D'Este et al., 2017). In this study L. digitata, a common macroalgae species in Danish waters, rich in sugars, has been used as substrate and nutrient source in heterotrophic microalgae cultivation. Sugars and nutrients from macroalgae are recovered by enzymatic hydrolyses and used to grow $C$. protothekoides to be used directly as fish feed. This work demonstrates that the protein content in the microalgae increased from 0.1 gProtein gDryMatter ${ }^{-1}$ to 0.4 gProtein $_{\text {gDryMatter }}{ }^{-1}$.

Therefore, the microalgae ability to easily adapt their metabolism to the environmental conditions such as temperature (Renaud et al., 2002), $\mathrm{pH}, \mathrm{O}_{2}$ or $\mathrm{CO}_{2}$ supply, salts 
(Garcia et al., 2012), nutrients, light or dark growth conditions (Graziani et al., 2013) changing their final chemical composition, enables to modify, control and optimize the formation of target compounds. Due to these reasons microalgae are an important source of amino acids representing an innovative trend for a future prospective (Kim, 2013).

\section{Conclusions}

This review analyzed the three processes applied in the manufacture of amino acids, namely, extraction from protein-hydrolysates, chemical synthesis and microbial methods, underlying the advantages and the drawbacks of these methods.

Due to economic and environmental advantages as well as to the development of new genetic engineering techniques, the fermentation is the most used process at industrial scale. Therefore, several studies involving mutagenesis and metabolic engineering approaches have been applied aiming to improve amino acid producing strains and thereby enhance amino acids productivity and expand the spectrum of products and feedstocks for fermentation. Owing to these technologies we are now able to produce amino acids using also residues and waste streams as feedstocks that do not compete with human food. Moreover, optimization of the downstream processing is crucial to reduce the production cost. The creation of microbial strains with improved amino acid productivity and lower by-product formation is essential to reduce the purification costs. Innovative separation techniques, such as the nanofiltration membranes, can be integrated in the classical fermenters combining production and purification in the same unit according to the principles of the process intensification. Furthermore, techniques able to mimic the behavior of bigger scale reactors such as computation fluid dynamics or the scale down devices can reduce the issues deriving from the scale-up of industrial bioreactors. Therefore, a combination of process modeling, simulations and metabolic engineering tools can lead to the development of the optimal process configuration in an early phase of the process design, thereby minimizing uncertainties in the process performance.

The potential of innovative approaches utilizing macro- and microalgae or bacteria was also presented. These approaches enable the conversion of a variety of inexpensive substrates and wastes into high quality proteins rich in essential amino acids. These features make them excellent candidates to produce protein supplements in human or food nutrition representing an innovative trend for the future.

\section{Acknowledgement}

This work was supported by the Danish Council for Strategic Research via the MacroAlgaeBiorefinery (MAB3) project.

\section{Conflict of interest}

The authors declare no financial or commercial conflict of interest.

\section{References}

Abou-taleb, K., 2015. Enhancing production of amino acids from Bacillus spp. using batch and fed-batch fermentation strategies. Br. Microbiol. Res. J.5: 257-272. 
Alvarado-Morales, M., Gunnarsson, I.B., Fotidis, I. A., Vasilakou, E., Lyberatos, G., Angelidaki I., 2015. Laminaria digitata as a potential carbon source for succinic acid and bioenergy production in a biorefinery perspective. Algal Res. 9:126-132.

Aoki, R., Wada, M., Takesue, N., Tanaka, K., Yokota, A., 2005. Enhanced glutamic acid production by a H+-ATPase-defective mutant of Corynebacterium glutamicum. Biosci. Biotechnol. Biochem. 69(2247):1466-1472.

Babi, D. K., Cruz, M. S., Gani, R., 2016. Fundamentals of Process Intensificatoin: A Process Systems Engineering View, in Sergovia-Hernández, J. G., Bonilla-Petriciolet, A. (Eds.), Process Intensificatoin in Chemical Engineering, Springer.

Becker, E.W., 2007. Micro-algae as a source of protein. Biotechnol. Adv. 25(2):207-10.

Becker, J., Zelder, O., Häfner, S., Schröder, H., Wittmann, C., 2011. From zero to heroDesign-based systems metabolic engineering of Corynebacterium glutamicum for Llysine production. Metab. Eng. 13:159-68.

Bommareddy, R.R., Chen, Z., Rappert, S., Zeng, A.P., 2014. A de novo NADPH generation pathway for improving lysine production of Corynebacterium glutamicum by rational design of the coenzyme specificity of glyceraldehyde 3-phosphate dehydrogenase. Metab. Eng. 25:30-7.

Bongaerts J., Krämer M., Müller U., Raeven L., Wubbolts M., 2001. Metabolic engineering for microbial production of aromatic amino acids and derived compounds. Metab. Eng. 3: 289-300.

Bott, M., 2007. Offering surprises: TCA cycle regulation in Corynebacterium glutamicum. Trends Microbiol. 15, 417-425. doi:10.1016/j.tim.2007.08.004

Brautaset, T., Jakobsen, Ø.M., Josefsen, K.D., Flickinger, M.C., Ellingsen T.E., 2007. Bacillus methanolicus: A candidate for industrial production of amino acids from methanol at $50^{\circ} \mathrm{C}$. Appl. Microbiol. Biotechnol. 74:22-34.

Bumbak, F., Cook, S., Zachleder, V., Hauser, S., Kovar, K., 2011. Best practices in heterotrophic high-cell-density microalgal processes: Achievements, potential and possible limitations. Appl. Microbiol. Biotechnol. 91(1):31-46.

Bylund, F., Collet, E., Enfors, S. O., Larsson, G., 1998. Substrate gradient formation in the large-scale bioreactor lowers cell yield and increases by-product formation.

Bioprocess Eng. 18: 171-180.

Campolo, M., Paglianti, A., Soldati, A., 2002. Fluid Dynamic Efficiency and Scale-up of a Retreated Blade Impeller CSTR. Ind. Eng. Chem. Res. 41:164-172.

Castan, A., Enfors, S.O., 2001. Formate accumulation due to DNA release in aerobic cultivations of Escherichia coli. Biotechnol. Bioeng. 77:324-328.

Cesari, M., Rossi, G.P., Sticchi, D., Pessina, A.C., 2005. Is homocysteine important as risk factor for coronary heart disease? Nutr. Metab. Cardiovasc. Dis. 15(2):140-147.

Chen X., Zhou L., Tian K., Kumar A., Singh S., Prior B. A., Wang Z., 2013. Metabolic engineering of Escherichia coli: a sustainable industrial platform for bio-based chemical production. Biotechnol. Adv. 31: 1200-1223

Cheng, H., Zhu, X., Zhu, C., Qian, J., Zhu, N., Zhao, L., Chen, J., 2008. Hydrolysis 
technology of biomass waste to produce amino acids in sub-critical water. Bioresour. Technol. 99: 3337-3341.

Cleto, S., Jensen, J.V., Wendisch, V.F., Lu, T.K. 2016. Corynebacterium glutamicum metabolic engineering with CRISPR interference (CRISPRi). ACS Synth. Biol. 5:375385 .

Costard, G.S., Machado, R.R., Barbarino, E., Martino, R.C., Lourenco, S.O., 2012. Chemical composition of five marine microalgae that occur on the Brazilian coast. Int. J. Fish. Aquacult. 4(9):191-201.

D’Este, M., Alvarado-Morales, M. , Angelidaki, I., 2017. Laminaria digitata as potential carbon source in heterotrophic microalgae cultivation for the production of fish feed supplement. Algal Res. 26: 1-7.

Delaunay, S., Lapujade, P., Engasser, J.M., Goergen, J.L., 2002. Flexibility of the metabolism of Corynebacterium glutamicum 2262, a glutamic acid-producing bacterium, in response to temperature upshocks. J. Ind. Microbiol. Biotechnol. 28:333337.

Delvigne, F., Destain, J., Thonart, P., 2006. A methodology for the design of scaledown bioreactors by the use of mixing and circulation stochastic models. Biochem. Eng. J. 28:256-268.

Desai, T. A., Rao, C. V., 2010. Regulation of Arabinose and Xylose Metabolism in Escherichia coli. Appl. Environ. Microbiol. 76:1524-1532.

Dominguez, A. A., Lim, W. A., Qi, L. S., 2016. Beyond editing: repurposing CRISPRCas9 for precision genome regulation and interrogation. Nature Rev. Mol. Cell. Biol. 17:5-15.

Drioli, E., Stankiewicz, A. I., Macedonio, F., 2011. Membrane engineering in process intensification-An overview. J. Memb. Sci. 380:1-8.

Ecker, J., Raab, T., Harasek, M., 2012. Nanofiltration as key technology for the separation of LA and AA. J. Memb. Sci. 389:389-398.

Eggeling, L., Oberle, S., Sahm, H., 1998. Improved L-lysine yield with Corynebacterium glutamicum: Use of dapA resulting in increased flux combined with growth limitation. Appl. Microbiol. Biotechnol. 49:24-30.

Eggeling, L., Bott, M., 2005. Handbook of Corynebacterium glutamicum. CRC PressTaylor \& Francis group.

Elmar, H., Arno, P. B., Charles, L. C., 2007. Development of Sustainable Bioprocesses: Modeling and Assessment. John Wiley \& Sons, Inc.

Enfors, S.O., Jahic, M., Rozkov, A., Xu, B., Hecker, M., Jürgen, B., Krüger, E, Schweder, T., Hamer, G., O'Beirne, D., Noisommit-Rizzi, N., Reuss, M., Boone, L., Hewitt, C., McFarlane, C., Nienow, A., Kovacs, T., Trägårdh, C., Fuchs, L., Revstedt, J., Friberg, P.C., Hjertager, B., Blomsten, G., Skogman, H., Hjort, S., Hoeks, F., Lin, H.Y., Neubauer, P., van der Lans, R., Luyben, K., Vrabel, P., Manelius, A. 2001. Physiological responses to mixing in large scale bioreactors. J. Biotechnol. 85:175-185.

Fleurence, J., 1999. Seaweed proteins: biochemical, nutritional aspects and potential 
uses. Trends Food Sci. Technol. 10(1):25-28.

Garcia, N., Lopez Elias, J.A., Miranda, A., Martinez Porchas, M., Huerta, N., Garcia, A., 2012. Effect of salinity on growth and chemical composition of the diatom Thalassiosira weissflogii at three culture phases. Lat. Am. J. Aquat. Res. 40(2):435440.

Gatenby, C.M., Orcutt, D.M., Kreeger, D. A., Parker, B.C., Jones, V. A., Neves, R.J., 2003. Biochemical composition of three algal species proposed as food for captive freshwater mussels. J. Appl. Phycol. 15(1):1-11.

Gnoth, S., Jenzsch, M., Simutis, R., Lübbert, A., 2007. Process analytical technology (PAT): batch to-batch-reproducibility of fermentation processes by robust process operational design and control. J. Biotechnol.132:180-186.

Gordon, D. M., 2013. The ecology of Escherichia coli, in: Donnenberg, M. S. (Eds.), Escherichia coli. Elsevier Inc., pp. 3-20.

Goto, M., Obuchi, R., Hirose, T., Sakaki, T., Shibata, M., 2004. Hydrothermal conversion of municipal organic waste into resources. Bioresour. Technol. 93:279-284.

Graziani, G., Schiavo, S., Nicolai, M.A., Buono, S., Fogliano, V., Pinto, G., Pollio, A., 2013. Microalgae as human food: chemical and nutritional characteristics of the thermoacidophilic microalga Galdieria sulphuraria. Food Funct. 144-152.

Gröger, H., 2003. Catalytic Enantioselective Strecker Reaction and Analogous Syntheses. Chem. Rev. 103:2795-2827.

Harada, K., 1963. Asymmetric Synthesis of $\alpha$-Amino acids by the Strecker Synthesis. Nature. 200:1201.

Hauer, B., Breuer, M., Ditrich, K., Habicher, T., Keßeler, M., Stürmer, R., Zelinski, T., 2004. Industrial methods for the production of optically active intermediates. Angew. Chemie - Int. Ed. 43: 788-824.

Hermann, T., 2003. Industrial production of amino acids by coryneform bacteria. J. Biotechnol. 104: 155-172.

Hirasawa, T., Shimizu, H., 2016. Recent advances in amino acid production by microbial cells. Curr. Opin. Biotechnol. 42:133-146.

Hsiao, H. Y., Walter, J. F., Anderson, D. M., Hamilton, B. K., 1988. Enzymatic production of amino acids. Biotechnology and Genetic Engineering Reviews 6: 179220.

Ikeda, M., 2003. Amino acids production processes, in: Scheper, T., Faurie, R., Thommel, J. (Eds.), Microbial Production of L-Amino Acids. Springer Berlin Heidelberg, pp. 1-35.

Ikeda, M., Katsumata, R., 1995. Tryptophan Production by Transport Mutants of Corynebacterium glutamicum. Biosci. Biotechnol. Biochem. 59:1600-1602.

Ikeda, M., Nakagawa, S., 2003. The Corynebacterium glutamicum genome: features and impacts on biotechnological processes. Appl. Microbiol. Biotechnol. 62(2-3):99109. 
Ikeda, M., Ohnishi, J., Hayashi, M., Mitsuhashi, S., 2006. A genome-based approach to create a minimally mutated Corynebacterium glutamicum strain for efficient L-lysine production. J. Ind. Microbiol. Biotechnol. 33:610-615.

Ikeda, M., Takeno, S., 2013. Amino Acid Production by Corynebacterium glutamicum, in: Yukawa H., Inui M. (Eds.), Corynebacterium glutamicum. Springer Berlin Heidelberg, Berlin, pp.107-147.

Inoue, M., Enomoto, S., 1982. Ammonolysis of trichloroethylene to glycine. Bull. Chem. Jpn. 55: 33-5.

Ivanov, K., Stoimenova, A., Obreshkova, D., Saso, L., 2014. Biotechnology in the production of pharmaceutical industry ingredients: amino acids. Biotechnol. Biotechnol. Equip. 27(2):3620-3626.

Junker, B., Lester, M., Brix, T., Wong, D., Nuechterlein, J., 2006. A next generation, pilot-scale continuous sterilization system for fermentation media. Bioprocess Biosyst. Eng. 28(6):351-378.

Käß, F., Junne, S., Neubauer, P., Wiechert, W., Oldiges, M., 2014. Process inhomogeneity leads to rapid side product turnover in cultivation of Corynebacterium glutamicum. Microb. Cell Fact. 13:6.

Kattan Readi, O. M., Rolevink, E., Nijmeijer, K., 2014. Mixed matrix membranes for process intensification in electrodialysis of amino acids. J. Chem. Technol. Biotechnol. $89: 425-435$.

Kelle, R., Hermann, T., Bathe, B., 2005. L-Lysine Production, in: Eggeling, L., Bott, M., 2005. Handbook of Corynebacterium glutamicum. CRC Press-Taylor \& Francis group, pp. 465-488.

Khamduang, M., Packdibamrung, K., Chutmanop, J., Chisti, Y., Srinophakun, P., 2009. Production of L-phenylalanine from glycerol by a recombinant Escherichia coli. J. Ind. Microbiol. Biotechnol. 36:1267-1274.

Khan, N.S., Mishra, I.M., Singh, R.P., Prasad, B., 2005. Modeling the growth of Corynebacterium glutamicum under product inhibition in L-glutamic acid fermentation. Biochem. Eng. J. 25, 173-178. doi:10.1016/j.bej.2005.01.025

Kim, S.K., 2013. Marine Proteins and Peptides: Biological Activities and Applications. John Wiley \& Sons, Ltd.

Kim, T-I., 2010. Beyond borders.Biotechnology Industry Report 2014.

Klejdus, B., Lojkova, L., Kula, E., Buchta, I., Hrdlicka, P., Kuban, V., 2008.

Supercritical fluid extraction of amino acids from birch (Betula pendula Roth) leaves and their liquid chromatographic determination with fluorimetric detection. J. Sep. Sci. 31: 1363-1373.

Kocabaş, P., Çalik, P., Özdamar, T.H., 2006. Fermentation characteristics of Ltryptophan production by thermoacidophilic Bacillus acidocaldarius in a defined medium. Enzyme Microb. Technol. 39(5):1077-1088.

Koma, D., Yamanaka, H., Moriyoshi, K., Ohmoto, T., Sakai, K., 2012. Production of aromatic compounds by metabolically engineered Escherichia coli with an expanded 
shikimate pathway. Appl. Environ. Microbiol. 78(17):6203-6216.

Koyoma, Y., Ishii, T., Kawahara, Y., Koyoma, Y., Shimizu, E., Yoshioka, T., 1998. Method for producing L-glutamic acid by continuous fermentation. European patent application EP844308.

Kuerová, Z., Tichá, M., 2009. The Shikimate Pathway: Aromatic Amino Acids and Phenylpropanoids, in: Dewick, P. M., Med. Nat. Prod. A Biosynthetic Approach. 3rd ed. John Wiley \& Sons, Ltd. pp. 121-166.

Kumagai, H., 2000. Microbial production of amino acids in Japan. Adv. Biochem. Eng. Biotechnol. 69:71-85.

Kumagai, H., 2013. Amino acid production, in: DeLong, E. F., Stackebrandt, E., Lory, S., Thompson, F. (Eds.), The Prokaryotes. Springer-Verlag Berlin Heidelberg, Berlin, pp. 169-177.

Kumar, M., Tripathi, B. P., Shahi, V. K., 2010.Electro-membrane process for the separation of amino acids by iso-electric focusing. J. Chem. Technol. Biotechnol. 85: $648-657$.

Kumar, R., Vikramachakravarthi, D., Pal, P., 2014. Production and purification of glutamic acid: A critical review towards process intensification. Chem. Eng. Process. 81:59-71.

Kurihara, K., 2009. Glutamate : from discovery as a food flavor to role as a basic taste (umami). Am. J. Clin. Nutr. 90:719-722.

Lara, A.R., Galindo, E., Ramírez, O.T., Palomares, L. A., 2006. Living with heterogeneities in bioreactors: understanding the effects of environmental gradients on cells. Mol. Biotechnol. 34:355-381.

Lemoine, A., Maya Martínez-Iturralde, N., Spann, R., Neubauer, P., Junne, S., 2015. Response of Corynebacterium glutamicum exposed to oscillating cultivation conditions in a two- and a novel three-compartment scale-down bioreactor. Biotechnol. Bioeng. 112:1220-1231.

Leuchtenberger, W., Huthmacher, K., Drauz, K., 2005. Biotechnological production of amino acids and derivatives: current status and prospects. Appl. Microbiol. Biotechnol. 69(1):1-8.

Liebl,W., 2005. Corynebacterium Taxonomy, in: Eggeling, L., Bott, M. (Eds.), Handbook of Corynebacterium glutamicum, Taylor \& Francis, pp. 9-34.

Longobardi, G. P., 1994. Fed-batch versus batch fermentation. Bioprocess Eng. 10: 185-194.

Lütke-Eversloh, T., Santos, C.N.S., Stephanopoulos, G., 2007. Perspectives of biotechnological production of L-tyrosine and its applications. Appl. Microbiol. Biotechnol. 77:751-762.

Matassa, S., Verstraete, W., Pikaar, I., Boon, N., 2016. Autotrophic nitrogen assimilation and carbon capture for microbial protein production by a novel enrichment of hydrogen-oxidizing bacteria. Water Res. 101, 137-146.

doi:10.1016/j.watres.2016.05.077 
Mänttäri, M., Van der Bruggen, B., Nyström, M., 2013. Nanofiltration, in:

Ramaswarny, S., Huang, H. J., Ramarao, B. V. (Eds.), Separation and Purification technologies in Biorefineris, John Wiley and Sons, pp.233-258.

März, U., 2009. World Markets for Fermentation Ingredients. Available from: http://www.bccresearch.com/market-research/food-and-beverage/fermentationingredients-fod020c.html (accessed 09.02.17)

Moritz, B., Striegel, K., De Graaf, A. A., Sahm, H., 2000. Kinetic properties of the glucose-6-phosphate and 6-phosphogluconate dehydrogenases from Corynebacterium glutamicum and their application for predicting pentose phosphate pathway flux in vivo. Eur. J. Biochem. 267:3442-3452.

Nasseri, A.T., Rasoul-Amini, S., Morowvat, M. H., Ghasemi, Y., 2011. Single Cell Protein: Production and Process. Am. J. Food Technol. 6:1-13.

Neubauer, P., Junne, S., 2010. Scale-down simulators for metabolic analysis of largescale bioprocesses. Curr. Opin. Biotechnol. 21(1):114-121.

Noor, R., Islam, Z., Munshi, S. K., Rahman, F., 2013. Influence of Temperature on Escherichia coli Growth in Different Culture Media. 7:899-904.

Ogata, Y., Inaishi, M., 1981. Preparation of DL-alanine by the reaction of $( \pm)-2$ cholopropionic acid with aqueous ammonia under pressure. Bull. Chem. Soc. Jpn. 54: 3605-3606.

Park J. H., Lee, K. H., Kim, T.Y., Lee, S. Y., 2007. Metabolic engineering of Escherichia coli for the production of L-valine based on transcriptome analysis and in silico gene knockout simulation. Proc. Natl. Acad. Sci. U. S. A. 104: 7797-7802.

Park, J.H., Lee, S.Y. 2010. Fermentative production of branched chain amino acids: a focus on metabolic engineering. Appl. Microbiol. Biotechnol. 85(3):491-506.

Park, J.H., Oh, J.E., Lee, K.H., Kim, J.Y., Lee, S.Y., 2012. Rational design of Escherichia coli for L-isoleucine production. ACS Synth. Biol. 1(11):532-540.

Patnaik, R., Zolandz, R.R., Green, D.A., Kraynie, D.F., 2008. L-tyrosine production by recombinant Escherichia coli: Fermentation optimization and recovery. Biotechnol. Bioeng. 99:741-752.

Paul, B.D., Sbodio, J.I., Xu, R., Vandiver, M.S., Cha, J.Y., Snowman, A.M., Solomon, H. S., 2014. Cystathionine $\gamma$-lyase deficiency mediates neurodegeneration in Huntington's disease. Nature. 509: 96-100.

Pittard J., Camakaris H., Yang J., 2005. The TyrR regulon. Mol. Microbiol. 55: 16-26.

Pollegioni, L., Servi, S., 2003. Unnatural amino acids methods and protocols. Humana Press.

Pourali, O., Asghari, F.S.,Yoshida, H., 2009. Sub-critical water treatment of rice bran to produce valuable materials. Food Chem. 115:1-7.

Ramakrishnan, V., Ghaly, A.E., Brooks M. S., Budge S. M.,2013. Enzymatic extraction of amino acids from fish waste for possible use as a substrate for production of jadomycin. Enz. Eng. 2:112. 
Ramos Tercero, E. A., Sforza, E., Morandini, M., Bertucco, A., 2014. Cultivation of Chlorella protothecoides with urban wastewater in continuous photobioreactor: Biomass productivity and nutrient removal. Appl. Biochem. Biotechnol. 172(3):14701485 .

Renneberg, R., 2008. High grade cysteine no longer has to be extracted from hair, in: Demain, A.L., (Eds.), Biotechnology for Beginners. Elsevier, p. 106.

Renaud, S.M., Thinh, L.-V., Lambrinidis, G., Parry, D.L., 2002. Effect of temperature on growth, chemical composition and fatty acid composition of tropical Australian microalgae grown in batch cultures. Aquaculture. 211(1-4):195-214.

Rittmann, D., Lindner, S.N., Wendisch, V.F., 2008. Engineering of a glycerol utilization pathway for amino acid production by Corynebacterium glutamicum. Appl. Environ. Microbiol. 74(20):6216-6222.

Rodriguez, A., Martínez, J. A., Flores, N., Escalante, A., Gosset, G., Bolivar, F., 2014a. Engineering Escherichia coli to overproduce aromatic amino acids and derived compounds. Microb. Cell Fact. 13:126.

Sabri, S., Nielsen, L. K., Vickers, C. E., 2013. Molecular Control of Sucrose utilization in Escherichia coli W, an Efficient Sucrose-Utilizing Strain. Appl. Environ. Microb. 79:478-487.

Sahm, H., Eggeling, L., de Graaf, A A., 2000. Pathway analysis and metabolic engineering in Corynebacterium glutamicum. Biol. Chem. 381:899-910.

Sano, C., 2009. History of glutamate production. Am. J. Clin. Nutr. 90:728S-732S.

Scheper, H., Lammers, F., 1994. Fermentation monitoring and process control. Curr. Opin. Biotechnol. 2:187-191.

Schmidt, F. R., 2005, Optimization and scale up of industrial fermentation processes. Appl. Micorbiol. Biotchnol. 68:425-435.

Sereewatthanawut, I., Prapintip, S., Watchiraruji, K., Goto, M., Sasaki, M., Shotipruk, A., 2008. Extraction of protein and amino acids from deoiled rice bran by subcritical water hydrolysis. Bioresour. Technol. 99:555-561.

Shu, C.H., Liao, C.C., 2002. Optimization of L-phenylalanine production of Corynebacterium glutamicum under product feedback inhibition by elevated oxygen transfer rate. Biotechnol. Bioeng. 77:131-141.

Singh, S., Gogoi, B.K., Bezbaruah, R.L., 2011. Racemic resolution of some DL-amino acids using Aspergillus fumigatus L-amino acid oxidase. Curr. Microbiol. 63:94-99.

Sprenger, G.A., 1995. Genetics of pentose-phosphate pathway enzymes of Escherichia coli K-12. Arch. Microbiol. 164: 324-330. doi:10.1007/s002030050270

Stincone, A., Prigione, A., Cramer, T., Wamelink, M.M.C., Campbell, K., Cheung, E., Olin-Sandoval, V., Grüning, N.M., Krüger, A., Tauqeer Alam, M., Keller, M.A., Breitenbach, M., Brindle, K.M., Rabinowitz, J.D., Ralser, M., 2015. The return of metabolism: Biochemistry and physiology of the pentose phosphate pathway. Biol. Rev. 90: 927-963. doi:10.1111/brv.12140

Strecker, A., 1850. Ueber die künstliche Bildung der Milchsäure und einen neuen, dem 
Glycocoll homologen Körper. Justus Liebigs Ann. Chem. 75: 27-45. doi:10.1002/jlac.18500750103

Suman, G., Nupur, M., Anuradha, S., Pradeep, B., 2015. Single Cell Protein Production: A Review. Int.J.Curr.Microbiol.App.Sci 4: 251-262.

Takors, R., 2012. Scale-up of microbial processes: Impacts, tools and open questions. J. Biotechnol. 160(1-2):3-9.

Tatarko M., Romeo T., 2001. Disruption of global regulatory gene to enhance central carbon flux into phenylalanine biosynthesis in Escherichia coli. Curr. Microbiol. 43: 26-32.

Transparency Market Research. Commercial Amino Acids Market - Global Industry Analysis, Market Share, Size, Growth, Trends, and Forecast, 2012 - 2018. 2013.

Ugimoto, M.S., 2010. Amino acids, production processes, in: Flickinger M. C. (Eds.), Encyclopedia of Bioprocess Technology. John Wiley \& Sons, pp. 1-11.

Utagawa, T., 2004. Production of arginine by fermentation. J. Nutr. 134(10):28542857.

Vaghari, H., Eskandari, M., Sobhani, V., Berenjian, A., Song, Y., Jafarizadeh-Malmiri, H., 2015. Process intensification for production and recovery of biological products. Am. J. Biochem. Biotechnol. 11: 37-43. doi:10.3844/ajbbsp.2015.37.43.

Villadsen, J., Lidén, G., Nielsen, J., 2011. Bioreaction Engineering Principles, third ed. Springer, New York.

Volker, F., 2006. Genetic Regulation of Corynebacterium glutamicum Metabolism. J. Microbiol. Biotechnol. 16:999-1009.

Weiner, M., Albermann, C., Gottlieb, K., Sprenger, G. A., Weuster-Botz, D., 2014. Fed-batch production of L-phenylalanine from glycerol and ammonia with recombinant Escherichia coli. Biochem. Eng. J. 83:62-69.

Weinert, D. J., 2009. Nutrition and muscle protein synthesis: a descriptive review. J. Can. Chiropr. Assoc. 53:186-193.

Wendisch, V.F., Jorge, J.M., Pérez-García, F., Sgobba, E., 2016. Updates on industrial production of amino acids using Corynebacterium glutamicum. World J. Microbiol. Biotechnol. 32:105.

Wittmann, C., Becker, J., 2007. The branched-chain amino acids, in: Amino Acid Biosynthesis. pp. 39-70. doi:10.1007/7171

Wu, G., 2009. Amino acids: metabolism, functions, and nutrition. Amino Acids. 37:1. doi:10.1007/s00726-009-0269-0 
Wu, G., Bazer, F. W., Cudd, T. A., Meininger, C. J., Spencer, T. E., 2004a. Maternal Nutrition and Fetal Development. J. Nutr. 134:2169-2172.

Wu, G., Fang, Y., Yang, S., Lupton, J. R., Turner, N. D., 2004b. Glutathione Metabolism and its Implications for Health. J. Nutr. 134:489-492.

Xu, H., Miao, X., Wu, Q., 2006. High quality biodiesel production from a microalga Chlorella protothecoides by heterotrophic growth in fermenters. J. Biotechnol. 126(4):499-507.

Yakandawala N., Romeo T., Friesen A.D., Madhyastha S., 2008. Metabolic engineering of Escherichia coli to enhance phenylalanine production. Appl. Microbiol. Biotechnol. 78: 283-291.

Yamane, H., Tomonaga, S., Suenaga, R., Denbow, D. M., Furuse, M., 2007. Intracerebroventricular injection of glutathione and its derivative induces sedative and hypnotic effects under acute stress in neonatal chicks. Neurosci. Lett. 418:87-91.

Yi J., Draths K.M., Li K., Frost J.W., 2003. Altered glucose transport and shikimate pathway product yields in E. coli. Biotechnol. Prog. 19: 1450-1459.

Yukawa, H., Inui, M., 2013. Corynebacterium glutamicum: Biology and Biotechnology, Springer.

Zahoor, A., Lindner, S.N., Wendisch, V.F., 2012. Metabolic engineering of Corynebacterium glutamicum aimed at alternative carbon sources and new products. Comput. Struct. Biotechnol. J. 3 (4):1-11.

Zhang, J., Zhang, S., Yang, X., Qiu, L., Gao, B., Chen, J., 2016. Reactive extraction of amino acids mixture in hydrolysate from cottonseed meal with di (2-ethylhexyl) phosphoric acid. J. Chem. Technol. Biotechnol. 91: 483-489.

Zhao, G., Gong, G., Wang, P., Wang, L., 2014. Enzymatic synthesis of L-aspartic acid by Escherichia coli cultured with a cost-effective corn plasm medium. Ann. Microbiol. 64:1615-1621.

Zhao, Z.J., Zou, C., Zhu, Y.X., Dai, J., Chen, S., Wu, D., Wu, J., Chen, J., 2011. Development of L-tryptophan production strains by defined genetic modification in Escherichia coli. J. Ind. Microbiol. Biotechnol. 38:1921-1929.

Zhou, L.B., Zeng, A.P., 2015a. Exploring lysine riboswitch for metabolic flux control and improvement of 1-lysine synthesis in Corynebacterium glutamicum. ACS Synth. Biol. 4:729-734.

Zhou, L.B., Zeng, A.P., 2015b. Engineering a lysine-ON riboswitch for metabolic control of lysine production in Corynebacterium glutamicum. ACS Synth. Biol. 4:13351340 . 
Zuend, S.J., Coughlin, M.P., Lalonde, M.P., Jacobsen, E.N., 2009. Scaleable catalytic asymmetric Strecker syntheses of unnatural alpha-amino acids. Nature. 461(7266):968970.

\section{Figure captions}

Figure 1: Embden-Meyerhof-Parnas pathway. In the first step of the pathway glucose is phosphorylated to glucose-6-phosphate using ATP by means of the hexokinase enzyme. Glucose-6-phosphate is then isomerized to fructose-6-phosphate by means of a reversible reaction catalyzed by phosphoglucose isomerase (PGI). A phosphate group was added to fructose-6-phosphate to convert it in fructose-2,6-bisphosphate by means of the enzyme phosphofructokinase (PFK). Aldolase catalyses the transformation of fructose-2,6-bisphosphate into dihydroxyacetone phosphate (DHAP) and glyceraldehyde-3-phosphate. Only glyceraldehyde-3-phosphate can be used in glycolysis so the enzyme triosephosphate isomerase (TIM) enables the transformation of DHPA into glyceraldehyde-3-phosphate. Glyceraldehyde-3-phosphate is converted to 1,3-bisphosphoglycerate by means of glyceraldehyde-3-phosphate dehydrogenase (GAPDH) and the reduction of $\mathrm{NAD}^{+}$to NADPH. Phosphoglycerate kinase (PGK) catalyzes the formation of ATP to ADP and the formation of 3-phosphoglycerate using a phosphate group of 1,3-bisphosphoglycerate. The transformation of 3phosphoglycerate to 2-phosphoglycerate is catalyzed by phosphoglycerate mutase (PGAM). The dehydration of 2-phosphoglycerate to phosphoenolpyruvate is obtained by means of the enzyme enolase. The final step is the phosphorylation of phosphoenolpyruvate to a molecule of pyruvate by means of pyruvate kinase (PK).

Figure 2: Tricarboxylic acid cycle scheme. The pyruvate deriving from the EmbdenMeyerhof-Parnas pathway is decarboxylated to acetyl-CoA, the starting point of the tricarboxylic acid cycle. The Tricarboxylic acid cycle is composed by eight enzymatic reactions. 1. conversion of acetyl-CoA to citrate through a condensation reaction catalyzed by citrate synthase (CS). 2 . citrate is then dehydrated and subsequently hydrated to isocitrate by means of aconitase $(\mathrm{ACN})$. 3. isocitrate is oxidated and carboxylated to 2-oxoglurate by the enzyme 2-oxoglutarate dehydrogenase complex (OGDHC). 4. 2-oxoglurate is decarboxylated to succinyl-CoA by means of succinylCoA-synthetase (SCS). 5. succinyl-CoA is phosphorylated to succinate by succinate: menaquinone oxidoreductase (SQO). 6 . succinate is oxidated to fumarate by means of fumarase (Fum). 7. fumarate is hydrated to malate by the enzyme malate: quinone oxidoreductase (MQO). 8. malate is oxidated to oxaloacetate.

Figure 3: L-lysine synthetic pathway in C. glutamicum. In the lysine synthetic pathway its precursor, oxaloacetate, is converted to aspartate by the addition of an amino-group taken from glutamate. The aspartate is then converted to L-4-aspartyl phosphate by phosphorylation by means of aspartate kinase (AK). A further conversion of L-4aspartyl phosphate to L-aspartate 4-semialdehyde was achieved by means of NADPH and the reaction was catalyzed by aspartate semialdehyde dehydrogenase (ASADH). Dihydrodipicolinate synthase (DHDPS) catalyzed the production of dehydrodipicolinate by reaction with pyruvate. Dehydrodipicolinate is further converted to L-piperidine 2,6dicarboxylate with the aid of the reducing agent NADPH and the enzyme 
dihydrodipicolinate reductase (DHDPR). L-piperidine 2,6-dicarboxylate can be directly converted to meso-2,6-diaminopimelate by addition of an amino-group by means of diamino pimelate dehydrogenase (DAPDH), or it can go through four successive reactions, involving tetrahydrodipicolinate succinylase (dapD), succinyl-amino ketopimelate transaminase (dapC), succinyl-amino pimelate succinylase (dapE) and diaminopimelate epimerase (dapF). The final step is the decarboxylation of meso-2,6diaminopimelate to lysine by menas of the enzyme diaminopimelate decarboxylase (DAPDC).

Figure 4: PPP of E.coli. Two different phases are present in the PPP, namely oxidative and non oxidative branches. In the first step of the oxidative branch glucose is phosphorylated to glucose-6-phosphate by means of the hexokinase enzyme. Glucose 6phosphate dehydrogenase (G6PD) catalyzed the dehydrogenation of glucose-6phosphate to 6-phospho-D-glucono-1,5-lactone with the production of NADPH. 6phospho-D-glucono-1,5-lactone is hydrated to 6-phospho-D-gluconate by means of 6phosphogluconolactonase (PGLS) and finally 6-phospho-D-gluconate is converted to D-ribulose-5-phosphate through an oxidative decarboxylation reaction catalyzed by 6phosphogluconate dehydrogenase (6PGD). In the non oxidative branch, through several steps catalyzed by transketolase enzyme (TKT), D-ribulose-5-phosphate is converted to D-glyceraldehyde-3-phosphate and D-fructose-6-phosphate.

Figure 5: Shikimate pathway. In the first step in the shikimate pathway an aldol-type condensation reaction takes place to combine the phosphoenolpyruvate and the Derythrose to give 3-deoxy-D-arabino-heptulosonic acid 7-phosphate (DAHP) by means of 3-Deoxy-D-arabino-heptulosonate-7-phosphate (DAHP synthase). The elimination of phosphoric acid from the DAHP to generate the 3-dehydroquinic acid represents the second step in the cycle, catalyzed by 3-dehydriquinate synthase (DHQ_synthase). 3dehydroquinic acid can then be reduced to quinic acid or dehydrated and reduced to 3dehydroshikimic acid by means of 3-dehydriquinate dehydratase (Dhquinase).

Protocatechuic acid and gallic acid can be form by secondary reactions, involving dehydration and enolization or dehydrogenation and enolization respectively, from 3dehydroshikimic acid. Shikimic acid is formed by dehydration and reduction of 3dehydroshikimic acid by means of the enzyme shikimate dehydrogenase. Shikimic acid is converted to shikimate 3-phosphate by means of the shikimate kinase enzyme. 5enolpyruvylshikimate-3-phosphate (EPSP) is formed by reaction of shikimate 3phosphate with phosphoenol pyruvate, catalyzed by EPSP synthase. Finally chorismate is obtained by means of the enzyme chorismate synthase. 


\section{Table captions}

Table 1: Comparison among different amino acid production methods. Advantages and disadvantages of the different methods are presented.

Table 2: Overview of yield obtained with different amino acids production methods.

Table 3: Overview of metabolic engineering strategies to improve amino acid production using different microorganisms. 
Table 1

\begin{tabular}{|c|c|c|c|}
\hline Process & Principle & Advantages & Disadvantages \\
\hline $\begin{array}{l}\text { Extraction from protein } \\
\text { hydrolysates }\end{array}$ & $\begin{array}{l}\text { An amino acid can be } \\
\text { separated from the } \\
\text { others present in the } \\
\text { protein-hydrolysates } \\
\text { if its properties are } \\
\text { different from the } \\
\text { others }\end{array}$ & $\begin{array}{l}\text { - Large scale } \\
\text { industrial } \\
\text { production (Ikeda, } \\
\text { 2003) } \\
\text { - Can use industrial } \\
\text { by-products or } \\
\text { waste (Hauer et } \\
\text { al., 2004) } \\
\text { - Common reagents } \\
\text { such as } \\
\text { hydrochloric acid } \\
\text { and sodium } \\
\text { hydroxide (Luitke- } \\
\text { Eversloh et al., } \\
\text { 2007) }\end{array}$ & $\begin{array}{l}- \text { Few kinds of amino } \\
\text { acids (Ikeda, 2003) } \\
\text { - Depend on the } \\
\text { availability of } \\
\text { natural protein rich } \\
\text { resources (Hauer et } \\
\text { al., 2004) } \\
\text { - Possible protein } \\
\text { degradation (Ikeda, } \\
\text { 2003) } \\
\text { - By-products (Heuer } \\
\text { et al., 2004) } \\
\text { - Wastewater } \\
\text { generation (Lütke- } \\
\text { Eversloh et al., } \\
\text { 2007; } \\
\text { Sereewatthanawut } \\
\text { et al., 2008) }\end{array}$ \\
\hline Chemical synthesis & $\begin{array}{l}\text { Amino acids obtained } \\
\text { through a chemical } \\
\text { reaction }\end{array}$ & $\begin{array}{l}\text { Produce achiral- } \\
\text { amino acids (Ivanov } \\
\text { et al., 2014) }\end{array}$ & $\begin{array}{l}\text { - Production of } \\
\text { racemic mixtures } \\
\text { additional optical } \\
\text { resolution step is } \\
\text { necessary to obtain } \\
\text { only the L-forms } \\
\text { (Ikeda, 2003) } \\
\text { - Price of the catalyst } \\
\text { (Heuer et al., 2004) } \\
\text { - Hazardous sources } \\
\text { (Zuend et al., 2009) }\end{array}$ \\
\hline Enzymatic synthesis & $\begin{array}{l}\text { Application of } \\
\text { proteases to peptide } \\
\text { hydrolysis }\end{array}$ & $\begin{array}{l}\text { - Produce optically } \\
\text { pure D and L- } \\
\text { amino acids } \\
\text { (Ikeda, 2003) } \\
\text { - Very few amount } \\
\text { of by-product } \\
\text { (Ivanov et al., } \\
\text { 2014) } \\
\text { - Simple process } \\
\text { downstream } \\
\text { (Ivanov et al., } \\
\text { 2014) }\end{array}$ & $\begin{array}{l}\text { - Price and instability } \\
\text { of the enzyme } \\
\text { (Ikeda, 2003) } \\
\text { - Not favorable for } \\
\text { production of L- } \\
\text { amino acids at } \\
\text { industrial scale } \\
\text { (Ikeda, 2003) }\end{array}$ \\
\hline Fermentation & $\begin{array}{l}\text { Microorganisms } \\
\text { convert the sugars } \\
\text { present in a substrate } \\
\text { into amino acids }\end{array}$ & $\begin{array}{l}\text { - Large scale } \\
\text { industrial } \\
\text { production of most } \\
\text { of L- amino acids } \\
\text { (Ivanov et al., } \\
\text { 2014) } \\
\text { - Economic method }\end{array}$ & $\begin{array}{l}\text { - Sterility has to be } \\
\text { ensured (Ugimoto, } \\
\text { 2010) } \\
\text { - Energy required for } \\
\text { oxygen transfer and } \\
\text { mixing (Ugimoto, } \\
\text { 2010) }\end{array}$ \\
\hline
\end{tabular}




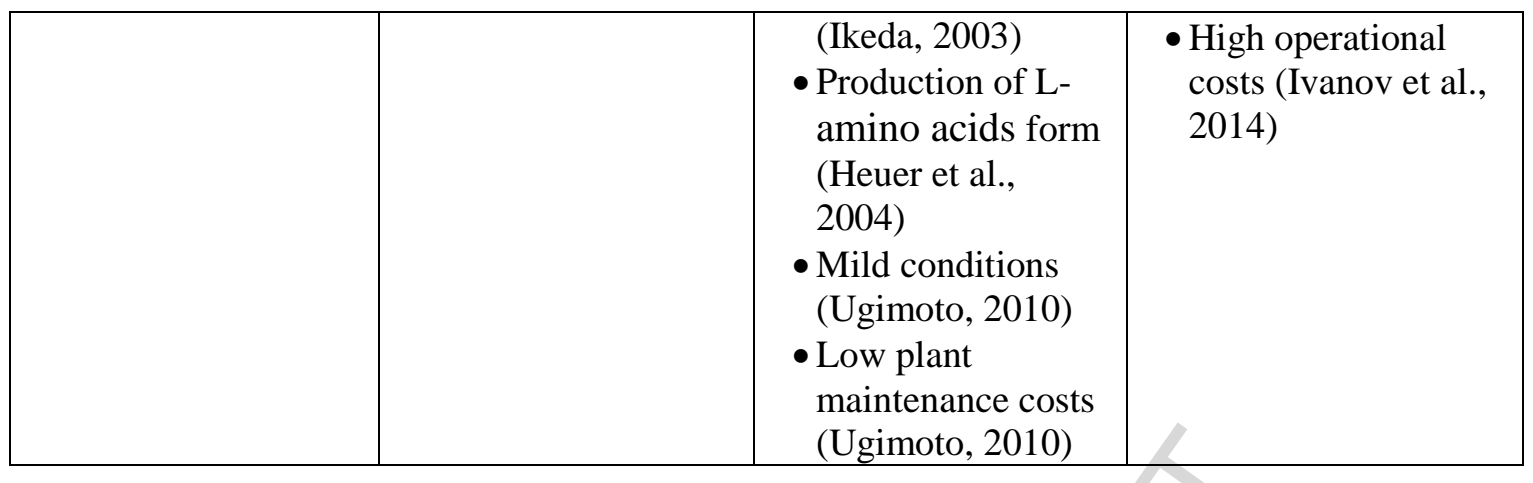


Table 2

\begin{tabular}{|c|c|c|c|c|c|}
\hline Method & Source & $\begin{array}{l}\text { Reaction }^{a} \text { or } \\
\text { enzyme }^{b}\end{array}$ & Amino acid & $\begin{array}{l}\text { Yield } \\
(\% w \\
\left.w^{-1}\right)\end{array}$ & Reference \\
\hline \multirow[t]{3}{*}{ Extraction } & Hair & - & L-cysteine & 10 & Renneberg, 2008 \\
\hline & Deoiled rice bran & - & Mixture & 0.8 & $\begin{array}{l}\text { Sereewatthanawut } \\
\text { et al. } 2008\end{array}$ \\
\hline & Feather & - & $\begin{array}{l}\text { L-leucine } \\
\text { L-alanine } \\
\text { L-serine }\end{array}$ & $\begin{array}{l}0.7 \\
0.1 \\
0.2\end{array}$ & Cheng et al. 2008 \\
\hline \multirow[t]{2}{*}{$\begin{array}{l}\text { Chemical } \\
\text { synthesis }\end{array}$} & Trichloroethylene & Ammonolysis $^{\mathrm{a}}$ & L-glycine & $40-70$ & $\begin{array}{l}\text { Inoue and } \\
\text { Enomoto } 1982\end{array}$ \\
\hline & $\begin{array}{l}( \pm)-2- \\
\text { chloropropionic } \\
\text { acid }\end{array}$ & Ammonolysis $^{\mathrm{a}}$ & DL-alanine & 78.0 & $\begin{array}{l}\text { Ogata and Inaishi } \\
1981\end{array}$ \\
\hline \multirow[t]{2}{*}{$\begin{array}{l}\text { Enzymatically } \\
\text { catalyzed } \\
\text { synthesis }\end{array}$} & Fish waste & $\begin{array}{l}\text { Alcalase and } \\
\text { Neutrase }^{\mathrm{b}}\end{array}$ & $\begin{array}{l}\text { L-alanine } \\
\text { L-glycine } \\
\text { L- } \\
\text { phenylalanine } \\
\text { L-leucine } \\
\text { L-serine }\end{array}$ & $\begin{array}{l}7.6 \\
5.8 \\
4.2 \\
9 \\
4.3\end{array}$ & $\begin{array}{l}\text { Ramakrishnan et } \\
\text { al. } 2013\end{array}$ \\
\hline & Phenylpyruvate & $\begin{array}{l}\text { Polyazetidine } \\
\text { immobilized } E \text {. } \\
\text { coli }^{\mathrm{b}}\end{array}$ & $\begin{array}{l}\text { L- } \\
\text { phenylalanine }\end{array}$ & 63 & Hsiao et al. 1988 \\
\hline
\end{tabular}


Table $3^{1}$

\begin{tabular}{|c|c|c|c|c|c|}
\hline Amino acid & Strain & $\begin{array}{l}\text { Relevant } \\
\text { characteristics }\end{array}$ & $\begin{array}{l}\text { Culture } \\
\text { conditions } \\
\left(\% \text { wt } v^{-1} .\right) \\
\end{array}$ & $\begin{array}{l}\text { Titer }^{a}\left(g^{-1}\right), \\
\text { or yield }^{b}\left(g_{A A}\right. \\
\left.g_{\text {sugar }}{ }^{-1}\right)\end{array}$ & Reference \\
\hline \multicolumn{6}{|c|}{ Corynebacterium glutamicum } \\
\hline \multirow{3}{*}{ L-lysine } & $\begin{array}{l}\mathrm{MH} 20- \\
22 \mathrm{~B} / \mathrm{pJC} 23\end{array}$ & $\begin{array}{l}\mathrm{AEC}\left(\mathrm{AK}^{\mathrm{IS}}\right) \text { and } \\
\mathrm{Leu}^{-}, \operatorname{dapA} \text { on } \\
\text { plasmid }\end{array}$ & $\begin{array}{l}\text { Glucose } \\
10 \%\end{array}$ & $50^{\mathrm{a}}$ & Ikeda, 2003 \\
\hline & AGM5 & $\begin{array}{l}\text { hom and } l y s C \\
\text { mutations in the } \\
\text { coding region }\end{array}$ & $\begin{array}{l}\text { Glucose } \\
50 \%\end{array}$ & About $90^{\mathrm{a}}$ & $\begin{array}{l}\text { Ikeda et al., } \\
2006\end{array}$ \\
\hline & Lys-12 & $\begin{array}{l}\text { Replacement of } t k t- \\
\text { operon by the sod } \\
\text { promoter }\end{array}$ & $\begin{array}{l}\text { Glucose } \\
10 \%\end{array}$ & $120^{\mathrm{a}}$ & $\begin{array}{l}\text { Becker et } \\
\text { al., } 2011\end{array}$ \\
\hline $\begin{array}{l}\text { L-glutamic } \\
\text { acid }\end{array}$ & F172-8 & $\begin{array}{l}\text { Reduced } \mathrm{H}^{+} \text {-ATPase } \\
\text { activity }\end{array}$ & $\begin{array}{l}\text { Biotin } \\
\text { limitation } \\
\text { Glucose } \\
10 \% \\
\end{array}$ & $0.55^{\mathrm{b}}$ & $\begin{array}{l}\text { Aoki et al., } \\
2005\end{array}$ \\
\hline L-tryptophan & KY9229 & $\begin{array}{l}\text { Defective in } \\
\text { aromatic uptake } \\
\text { system, introduction } \\
\text { of plasmid pCA5 } \\
\text { which contained a } \\
\text { gene region involved } \\
\text { in the uptake of } \\
\text { aromatic amino } \\
\text { acids }\end{array}$ & $\begin{array}{l}\text { Molasses } \\
\text { (glucose) } \\
25 \%\end{array}$ & $35^{\mathrm{a}}$ & $\begin{array}{l}\text { Ikeda and } \\
\text { Katsumata, } \\
1995\end{array}$ \\
\hline \multicolumn{6}{|c|}{ Escherichia coli } \\
\hline L-lysine & BL21 (DE3) & $\begin{array}{l}\text { Contain the } \\
\text { phenylalanine } \\
\text { dehydrogenase gene } \\
\text { of Acinetobacter } \\
\text { lwoffii }\end{array}$ & Glycerol 1\% & $0.58^{\mathrm{b}}$ & $\begin{array}{l}\text { Khamduang } \\
\text { et al., } 2009\end{array}$ \\
\hline \multirow[t]{2}{*}{$\begin{array}{l}\text { L- } \\
\text { phenylalanine }\end{array}$} & $\begin{array}{l}\text { MG1655 } \\
\text { derivative }\end{array}$ & $\begin{array}{l}\text { Deletion of pheA, } \\
\text { pheL and } \\
\text { replacement of tyrA } \\
\text { native chromosomal } \\
\text { promoter with a } \\
\text { strong } t r c \text { promoter }\end{array}$ & Glucose $3 \%$ & $51^{\mathrm{a}}$ & $\begin{array}{l}\text { Patnaik et } \\
\text { al., } 2008\end{array}$ \\
\hline & $\begin{array}{l}\text { FUS4.11/pF81 } \\
\text { kan (W3110 } \\
\text { derivative) }\end{array}$ & $\begin{array}{l}p y k A \text { gene deleted } \\
\text { and } p y k F \text { disrupted }\end{array}$ & $\begin{array}{l}\text { Glycerol and } \\
\text { lactic acid } \\
16 \%\end{array}$ & $0.15^{\mathrm{b}}$ & $\begin{array}{l}\text { Weiner et } \\
\text { al. } 2014\end{array}$ \\
\hline L- tryptophan & $\begin{array}{l}\text { FB-04/pSV03 } \\
\text { (W3110 } \\
\text { derivative) }\end{array}$ & $\begin{array}{l}\text { Deletion of trpR, } \\
\text { tnaA, phe } A \text { and } t y r A \\
\text { genes }\end{array}$ & $\begin{array}{l}\text { Glucose } \\
0.5 \%\end{array}$ & $13.3^{\mathrm{a}}$ & $\begin{array}{l}\text { Zhao et al. } \\
2011\end{array}$ \\
\hline
\end{tabular}

1 AEC, S-(2-aminoethyl)-L-cysteine; AK, aspartate kinase; ${ }^{\text {IS }}$, insensitive to feedback regulation; $\operatorname{dap} A$, dihydrodipicolinate synthase gene; hom, homoserine dehydrogenase gene; lys $C$, aspartate kinase gene; $t k t$, transketolase; sod, superoxide dismutase; pheA, bifunctional chorismate mutase/prephenate dehydratase; $p h e L$, phe operon leader peptide; $t y r A$, chorismate mutase/prephenate dehydrogenase; $p y k A$, pyruvate kinase II; $p y k F$, pyruvate kinase I; $\operatorname{tr} p R$, tryptophan transcriptional repressor; tnaA, tryptophanase. 


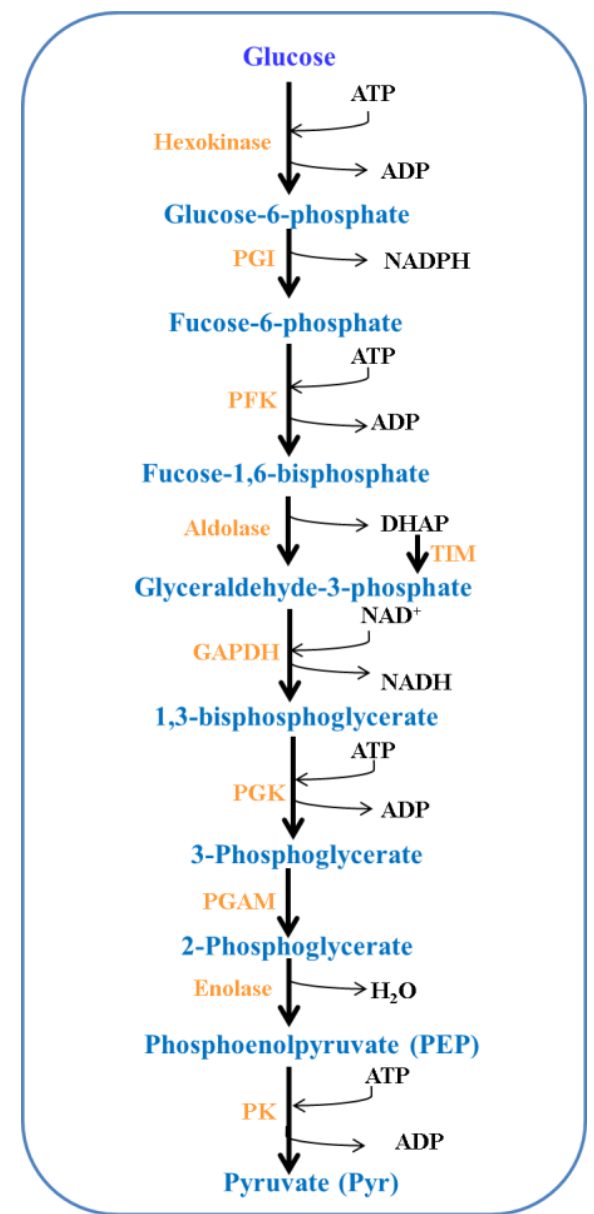

Figure 1 


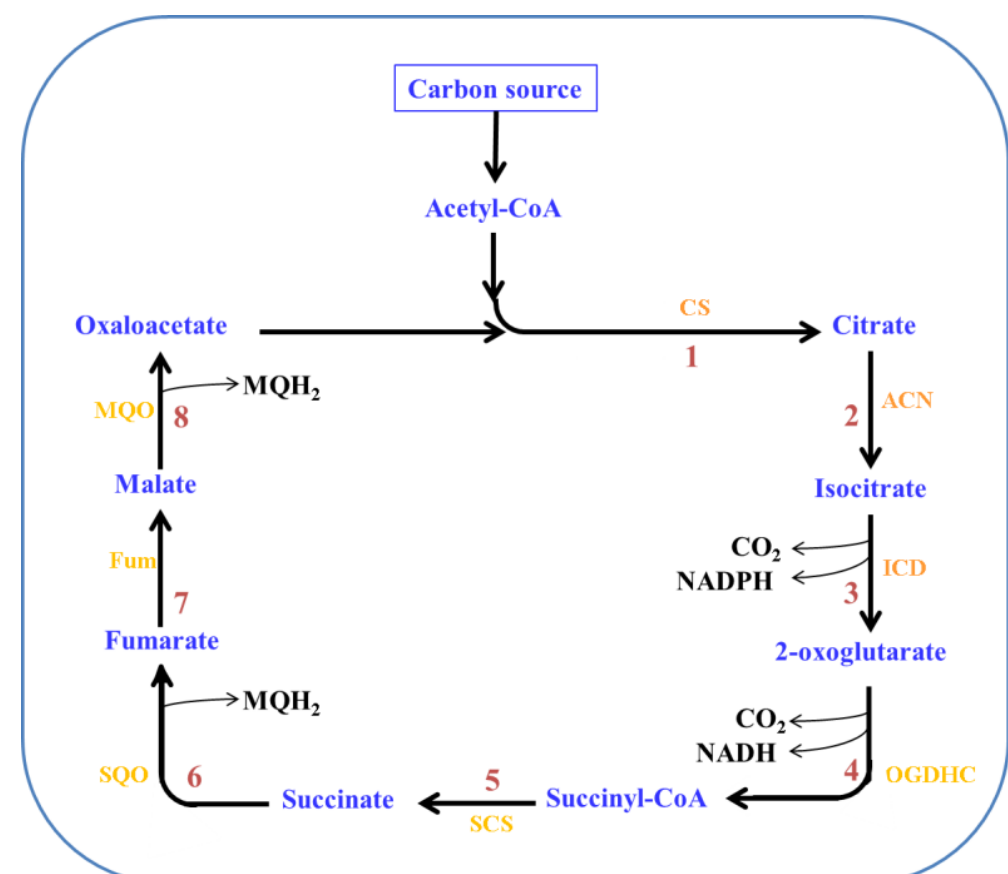

Figure 2 


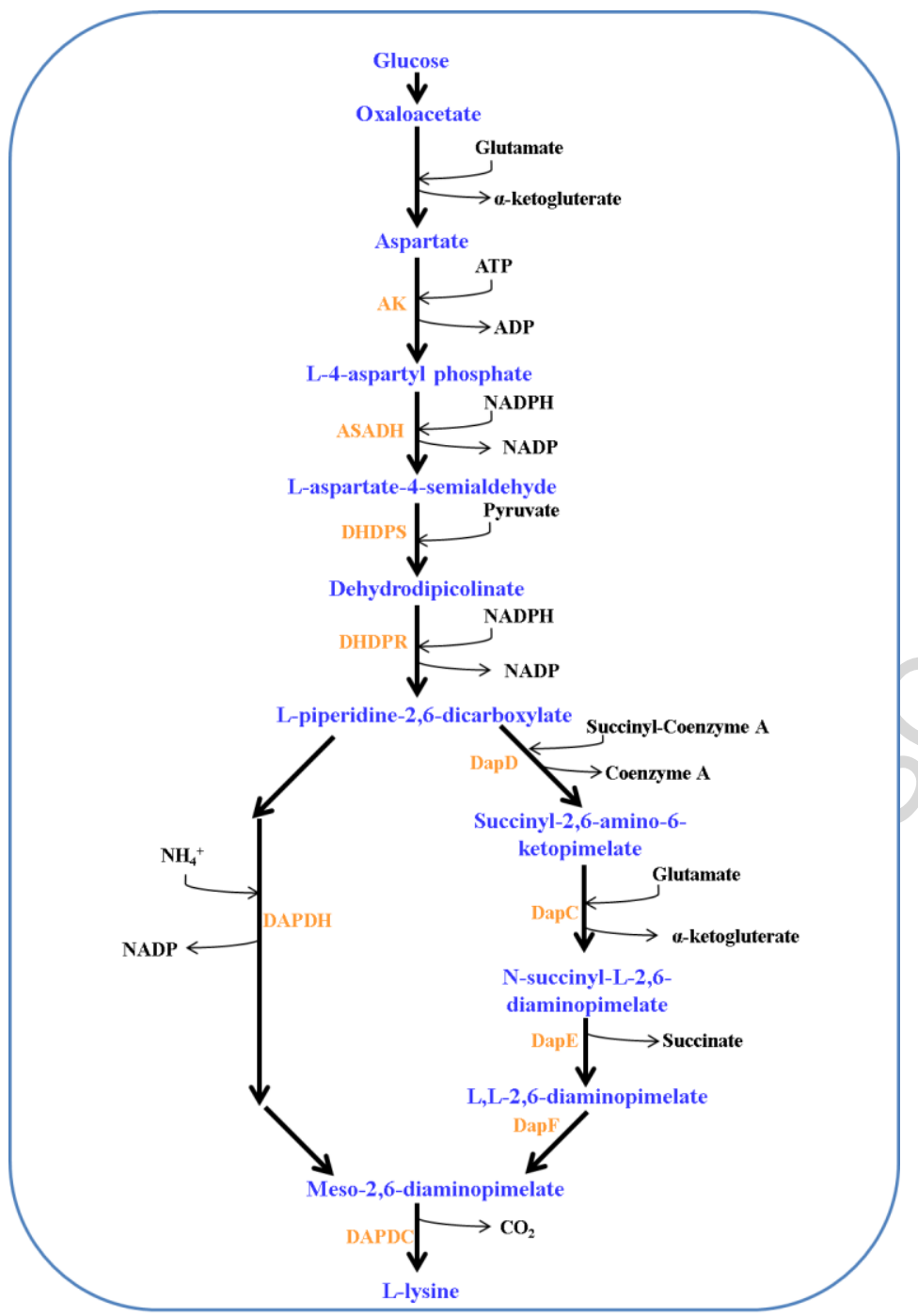

Figure 3 

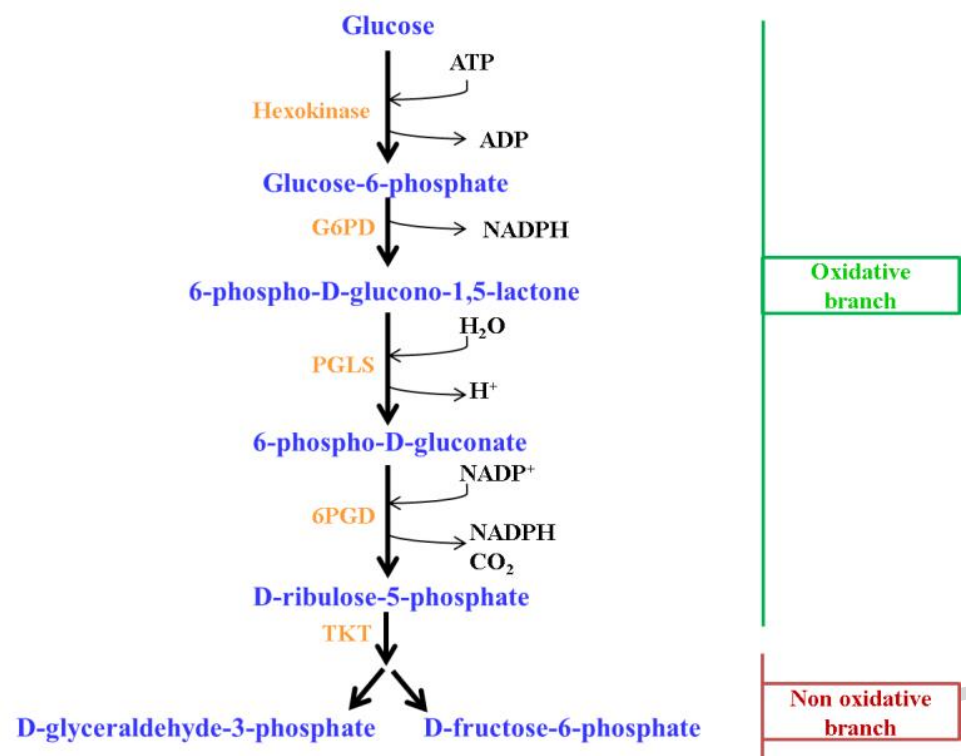

Figure 4 


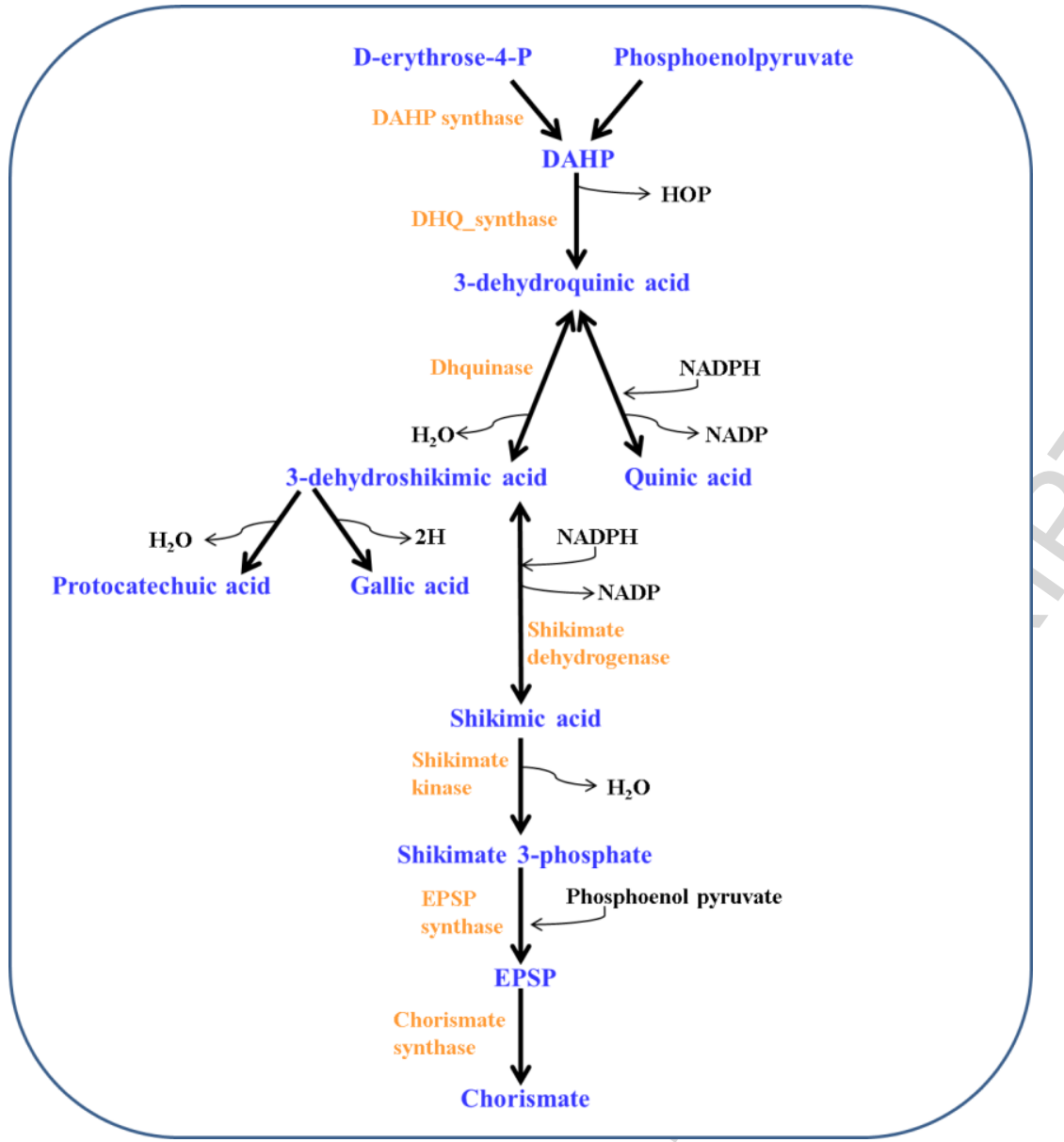

Figure 5 